Water International. https://doi.org/10.1080/02508060.2019.1665967

\title{
A comprehensive framework for analyzing co-production of urban water and sanitation services in the Global South
}

Giuseppe Faldi ${ }^{1}$, Federica Natalia Rosati ${ }^{1,2}$, Luisa Moretto ${ }^{1}$, Jacques Teller ${ }^{2}$

(1) Faculty of Architecture, Université libre de Bruxelles (ULB), Belgium

(2) LEMA, Urban and Environmental Engineering Department, University of Liège, Belgium

\section{Corresponding author:}

Giuseppe Faldi

Faculty of Architecture La Cambre Horta, ULB-Université libre de Bruxelles

Place Flagey 19, 1050 Brussels, Belgium

Email: giuseppe.faldi@ulb.ac.be

This research was funded by FNRS grant T.0174.16, in the framework of the PRD project Typologies of Institutionalised Co-production of Water and Sanitation Services in the Urban South (TYCO-WSS). 


\title{
A comprehensive framework for analyzing co-production of urban water and sanitation services in the Global South
}

\begin{abstract}
Co-production of water and sanitation services has become a widely discussed option for equitable and efficient service delivery, especially for cities of the Global South. Theoretical conceptualizations of service co-production mainly refer to the public management and governance dimension, while the technoenvironmental and spatial dimensions are often disregarded in the literature. This paper proposes a comprehensive framework for analyzing water and sanitation coproduction based on cross-cutting literature, from public service management/governance to urban, socio-ecological and socio-technical fields. The proposed framework highlights the categories and factors to be considered when analyzing the background conditions and outcomes of unorthodox service delivery.
\end{abstract}

Keywords: co-production; water and sanitation services; urban; socio-ecological; socio-technical; Global South

\section{Introduction}

Poor access to water and sanitation remains an urgent issue in many cities of the Global South ${ }^{\mathrm{i}}$. Respectively more than 500 million and 1.5 billion people in urban areas of the Global South have no access to safely managed drinking water and sanitation services (World Health Organization [WHO]/United Nations International Children's Emergency Fund [UNICEF], 2015). Rapid urbanization occurring in these areas ${ }^{\text {ii }}$ hampers the institutional capacity of public authorities and water utilities to organize service delivery, especially as water demand and pollution increase very rapidly. Poor infrastructure, high levels of non-revenue water, growing tariffs and ineffective governance contribute to degradation of the quality of water supply and sanitation (WSS) services, inability to upgrade the systems and consequently affect consumers' willingness to pay (United Nations World Water Assessment Programme [WWAP], 
2015).

In this context, the construction and operation of water and sanitation infrastructure has long been undertaken by public agencies or delegated to private, forprofit, contractors. However, as many authors argue, there is no evidence that centralized delivery of public services is efficient or equitable (Mitlin, 2008; Ostrom, 1996). The modern ideal of standardized universal provision of WSS services through a centralized infrastructure network may not be adequate in all Global South cities (Coutard, 2008; Coutard \& Rutherford, 2015; Fernandez-Maldonado, 2008; Furlong, 2014; Graham \& Marvin, 2001; Kooy \& Bakker, 2008; Moretto \& Ranzato, 2017; Jaglin, 2012; Zérah, 2008). Many governments and private companies have failed in their provision of adequate services to the poor and in addressing the causes that undermine individual access. Due to poor economic and planning capacities, providers are unable to cope with increasing population, urban densification in poorest areas and rapid sprawl of the peri-urban interface, characterized by low densities and greater distances to the centralized networks (Allen, Davila, \& Hofmann, 2006a, 2006b; Bakker, Kooy, Shofiani \& Martijn, 2008; Coutard, 2008; Dos Santos et al., 2017; Furlong, 2014; Jaglin, 2008).

In the limited capacity of conventional networked services, many urban and peri-urban communities of the Global South rely on localized and user-driven arrangements for accessing water and sanitation (Coutard \& Rutherford, 2015; Bakker, 2003; Furlong, 2014; Jaglin, 2012; McGranahan, 2013; Moretto \& Ranzato, 2017). Non-professional actors develop such solutions on a daily basis, individually or collectively, with or without support from the state and public utilities (Allen, Hofmann, Mukherjee, \& Walnycki, 2017). In most of these areas, WSS services are characterized by multiple coexisting systems complementary to the centralized network, an 
"archipelago" of community-based services and/or for-profit practices of reselling/redistribution (Allen et al., 2017; Bakker, 2003; Furlong, 2014; Kjellen, 2000), whose extension is context specific.

In terms of equity, the failure of the ideal of WSS service universalization through a centralized network has somehow favoured socio-spatial segregation, leading to elite service islands or limiting the unfolding of alternative solutions (Coutard, 2008; Coutard \& Rutherford, 2015; Dill, 2010; Furlong, 2014; Pflieger \& Matthieussent, 2008; Jaglin, 2008). At the same time, the consequent service fragmentation has frequently been considered as a cause of economic, environmental and spatial injustice among the poorest inhabitants. It has contributed to increase the cost gap for WSS provision among inhabitants and areas (both in terms of price/unit and indirect cost for compensatory technology supply) and to environment degradation in high-density settlements (Andreasen \& Møller-Jensen, 2016; De \& Nag, 2016; Domenech, 2011; Dos Santos et al., 2017; Furlong, 2014).

In many cities of the Global South, the need to provide services to a growing population challenges conventional planning, management approaches and userprovider relationships. Accordingly, greater attention to different user-provider arrangements and the role of users in producing services has recently increased in international and scientific communities (Joshi \& Moore, 2004; McGranahan, 2013; McMillan, Spronk, \& Caswell, 2014; Mitlin, 2008; Moretto \& Ranzato, 2017; United Nations [UN], 2016a). The concept of co-production was initially developed in public governance and management fields. Co-production was once defined as "the process through which inputs used to produce a good or service are contributed by individuals who are not 'in' the same organizations. (...) Co-production implies that citizens can play an active role in producing public goods and services of consequence to them' 
(Ostrom, 1996, p. 1073). The co-production of basic services is now a recognized approach for service delivery at the international level. Article 117 of the United Nations Policy paper 9: Urban services and technology, prepared for the conference Habitat III, states that 'local governments should (...) promote co-production of basic services with local communities, particularly in informal settlements and slums' (UN, 2016a, p. 22). Co-production increasingly appears to be a valuable alternative for delivering water and sanitation services to the urban poor, especially because it can improve the effectiveness and efficiency of local governments' action (Parks et al., 1981, p. 1001).

Notwithstanding this growing interest, the theoretical background of service coproduction is primarily drawn from the public management and governance disciplines, which mainly explored cases of service co-production in the North. Most research on co-production addresses the motivations behind co-production, its institutional settings and its benefits in service management (Pestoff, Brandsen, \& Verschuere, 2012; van Eijk \& Steen, 2014). By contrast, the techno-environmental dimension of co-production is often ignored in the literature. This dimension is, however, critical to the effective coproduction of WSS services. In addition, the public management and governance literature fails to fully acknowledge the growing interest for physical space as both an output and a determinant of socio-political configurations evident in the social and political sciences (Bates \& Smith, 2008; Pugh, 2009). Space should be regarded as an essential dimension of co-production, especially in the context of Global South cities where spatial differentiations are very significant from ecological, social and political perspectives.

In this paper, a comprehensive framework for analyzing the co-production of WSS services is proposed. This framework takes into account the managerial, techno- 
environmental and spatial dimensions of co-production. It is based on different strands of literature, from public service management and governance to urban, socioecological and socio-technical studies. It reviews theoretical studies on service coproduction, as well as multiple case studies of water and sanitation co-production taking place in cities of the Global South. As such, it will help bridge the gap in the conceptualization of the co-production of WSS services that exists within public administration and management scholarships, particularly when employing the concept in the case of urban environments of the Global South. A multidisciplinary set of factors for the analysis of WSS service conditions and outcomes is included within the proposed framework. Validation and limitations of the framework are discussed in the final part of the paper by referring to the preliminary results from the application of the framework in three cities of the Global South.

\section{The specificity of water and sanitation service co-production: the need for a comprehensive framework}

Conceptualized in the early 1970s by Elinor Ostrom, co-production entered the debate on service provision as an alternative to the dominant theories of urban governance in force at the time, which mainly considered policymaking as a top-down process (Bovaird, 2007; Nabatchi, Sancino, \& Sicilia, 2017). By analysing two cases of coproduction of WSS and education in Brazil and Nigeria respectively, Ostrom challenged the separation of the market from the state, and governments from civil society, suggesting that citizens could themselves contribute to service provision (Ostrom, 1996).

Co-production theories have gained renewed attention in the 21 st century for a wide range of actors, from the policy sector to academia and practice, and in both nonprofit and private spheres. As suggested by Nabatchi et al. (2017, p. 767), the 
'recognition of the multi-sectoral nature of governance' calls for a model of service delivery based on more horizontal and collaborative relationships. Co-production promises much in this context, as it is characterized by both a normative value, because it can deepen citizenship and help to promote more collaborative governance during coproduction process, and an instrumental value, because it can improve the efficiency and quality of services as outcomes of the practice ${ }^{\mathrm{iii}}$ (Nabatchi et al., 2017, p. 767).

Most studies on co-production have been within the public governance and management domains. Although Ostrom's seminal work on co-production moved from two cases in the South, the majority of the following studies have referred to cases of co-production in the North or have explored generalized aspects of co-production without specifically considering the differences between South and North (Cepiku \& Giordano, 2014). To date, research has mainly addressed services such as health, education and security, with a primary focus on management (Osborne \& Strokosch, 2013; Pestoff et al., 2012) and facilitation of co-production through public governance systems (Bovaird, 2007; Bovaird \& Loeffler, 2012; Verschuere, Brandsen, \& Pestoff, 2012). In addition, a number of papers related to alternative WSS services in the Global South cities have been undertaken within urban studies. That research mainly focused on relations between informal and formal systems, considering co-production as one of the available options for involving a range of different actors in service delivery (Allen, 2013; Katsongo, 2012) or for securing citizens' political influence (McMillan et al., 2014; Mitlin, 2008). Many studies addressing water co-production are centred on individual cases. They mainly emphasize individual aspects of the co-production model without proposing a comprehensive analytical framework. 
Existing research can be divided in two complementary approaches. The first addresses the management and institutional dimension, and the second addresses the techno-environmental dimension.

From a management and institutional perspective, it has been argued that the participatory nature of co-production of basic services, such as water and sanitation, contributes to the development of skills and capacities, and thereby empowers citizens (Allen, 2013; Mitlin, 2008). Mitlin (2008) suggests that by involving groups of citizens in civic action, co-production facilitates a creative process leading to growing social capital and stronger horizontal relations. By reducing the distance between development experts and communities, co-production challenges the existing state-society relationship and increases the political capacity of the poor to claim their rights, within appointed institutions. As an example, Moretto (2010) shows how, beyond the concrete outcome of improved water services, co-production of WSS services allows residents of informal areas to claim and legitimize their presence on occupied land. However, while co-production has the capacity to incorporate informal practices and state-community relationships in the process of services provision, it cannot be taken for granted that this model will overcome state and market failures. It may also be subject to resource capture by elites and to management conflicts among groups, resulting in discrimination and exclusion of certain individuals from access to services (Ahlers, Cleaver, Rusca, \& Schwartz, 2014; McMillan et al., 2014).

From a techno-environmental perspective, in Global South cities, water supply co-production usually includes socio-technical arrangements either decentralized (e.g., community urban well, rainwater harvesting system) or hybrid (i.e. unofficial network extensions of centralized piped water systems, possibly integrating municipal water with new water sources and/or the use of complementary technology), which extend 
proportionally to the deficiencies of the centralized system (Allen et al., 2017; Bakker, 2003; Domenech, 2011; Moretto et al., 2018). Co-production of sanitation systems mainly involve on-site facilities (e.g., shared pit latrine and septic tank, biogas production system) or simplified sewerage systems connected to decentralized wastewater treatment plants (Allen, 2010; Domenech, 2011; Moretto et al., 2018; Wilderer \& Schreff, 2000).

Studies on urban WSS in the Global South (Ali, 2010; De \& Nag, 2016; Domenech, 2011; McGranahan, 2013; Opryszko, Huang, Soderlund \& Shwab, 2009) mostly associate benefits of service decentralization within its capacity to ensure users' adaptability to contextual water stress problems and to reduce capital and distribution costs of the infrastructure. Shortcomings are found in relation to the challenges of guaranteeing a sustainable management of the system, maintaining service equity and efficiency, and ensuring water and environmental standards.

The environmental and spatial questions associated with WSS co-production are particularly relevant. WSS services convey material products as processed 'natural resources' (Moretto \& Ranzato, 2017) and are, therefore, the 'key catalysts of environmental problems' and at the same time an 'important key to solving them' (Monstadt, 2009, p. 1926). A co-evolutionary dynamic between socio-spatial urban patterns and co-production arrangements can emerge (Moretto et al., 2018). Coproduction can reinforce urban fragmentation (Cabrera, 2015) when diversification of socio-technical infrastructures in the city fosters creation of urban service zones that are socially and spatially unconnected between each other (Moretto et al., 2018). Coproduction can lead to environmental decay and overexploitation of natural resources (Ranzato \& Moretto, 2018) when local socio-technical infrastructures fail to consider the circularity of the water service cycle (Moretto et al., 2018). It should be 
acknowledged that co-production does not guarantee sustainability in urban WSS service provision and cannot be considered as a 'panacea'. It may raise social, environmental and economic issues, which have to be evaluated against sustainable urban service provision criteria.

A comprehensive framework is essential to address the opportunities and challenges raised by co-production of WSS services in the cities of the Global South. Moretto and Ranzato (2017) examined co-production of urban services from two perspectives: firstly, with respect to the objective of guaranteeing and enhancing accessibility to services, based on social, political, economic and governance structures; secondly, with respect to their capacity to improve the use of the environmental resources they convey (Moretto \& Ranzato, 2017, p. 5). We build upon this preliminary framework to provide a comprehensive understanding of the theoretical and analytical implications of co-production of WSS services.

\section{The actor/flow/area framework}

The need to reconcile a public management and governance perspective with a technoenvironmental perspective in conceptualizing co-production of conventional services was the starting point of the recent work of Moretto and Ranzato (2017). They recognized that urban service co-production has environmental and spatial implications, and therefore a comprehensive approach is needed for analyzing their sustainability, an approach able to grasp the 'mutual inference' between 'access to resource or services' and 'environmental and habitat-related problems' (Robertson, 2012, p. 3 in Moretto \& Ranzato, 2017).

Political ecology proposes a theoretical platform for considering physical and social conditions, in a specific context, and their causal relationships, all from an 
ecological perspective (Heynen, Kaika, \& Swyngedouw, 2006; Robertson, 2012). Moretto and Ranzato (2017) developed a framework for understanding conventional services co-production (water, energy and waste) capable of addressing the physical and social conditions of a context through a threefold conceptual perspective based on actor/flow/area dimensions. These may be considered as defining factors for the planning process (Moretto \& Ranzato, 2017, p. 6).

Within this framework, the actor dimension refers to the variety of stakeholders involved in alternative service delivery as well as their institutional and political configurations. Agents involved in co-production (e.g., from users/citizens to coproducers) can be engaged in different forms of participation (individual, collective), and have different levels of inclusion in the decision-making process, within a wide range of activities at various phases of the service cycle.

The flow dimension involves the organization and management of resources, used for and produced by the service delivery process. Looking at the metabolic transformations within the flow dimension implies an understanding of the life cycle of the resource, from extraction to processing and waste, and the direct influence of users on the trajectories of delivered materials (i.e., recycling, reusing, collecting and separating).

The area dimension involves the relationship between the service delivered and its urban/spatial context. Service accessibility and resources may be unevenly distributed. Analysis of their distribution reveals the ways in which socio-technical services shape, and are shaped by, the space and the territory. Detailing the area dimension requires understanding of the service at different spatial scales, the form of land occupation by the service recipients, and the spatial integration of the infrastructure 
with the characteristics of the territory and with related social organization arrangements.

The actor/flow/area framework combines the managerial and technoenvironmental perspectives into a unified and coherent system through consideration of the spatial dimension of co-production. This three-dimensional approach is key to addressing urbanization challenges in the Global South cities. The framework acknowledges that ecological factors affect and are affected by the co-production of services such as water and sanitation that rely heavily on natural resources. The framework is therefore a valuable starting point in the mapping of the various "geographies" of WSS service co-production. However, further research is required to define and specify the categories and factors related to these three dimensions. A deeper understanding of the contribution of techno-environmental and spatial factors in the framing of conventional services, such as water and sanitation, is clearly required.

\section{Exploring the three dimensions of the actors-flow-area framework: the complexity of water and sanitation co-production}

Water and sanitation co-production can be considered as a complex system made up of interactions between three spheres or dimensions (Figure 1): i) the managerial dimension, which includes the relationships between users, intermediaries and providers, ii) the techno-environmental dimension composed of the technical infrastructures for the treatment and distribution of resources (considering their metabolic flows), and iii) the spatial dimension, which responds to the socio-spatial configuration of accessibility to the service, considered at overlapping geographical scales from the household to the regional level (Monstadt, 2009).

[Figure 1 near here] 
A review of the scientific literature on theories and cases of co-production has elicited the main elements, among these three inter-related dimensions, which contribute to evaluation of WSS service outcomes. Our purpose in this paper is to build a comprehensive framework that helps researchers in determining co-production cases, in identifying potential factors to be considered for understanding WSS co-production, and in undertaking comparative analysis. In building the structure of the framework, we made reference to literature on case-based qualitative analysis (Miles \& Huberman, 1994; Onwuegbuzie \& Weinbaum, 2017; Rihoux \& Lobe, 2009; Ritchie \& Lewis, 2003), by hierarchically sorting the conceptual dimensions of WSS service coproduction into categories, analytical factors and their attributes.

In the first step, our literature survey considers existing studies that sought to conceptualize the actors and the techno-environmental dimensions of service coproduction. We rely on specialized literature on public service management and governance, which have extensively explored generalized characteristics of service coproduction, as well as on socio-ecological and socio-technical domains. Socioecological principles, originally developed for analysing factors of sustainability in rural community-based initiatives relying on common resources (Ostrom, 1990, 2009), have been recently applied for studying social and ecological performance of decentralized or hybrid urban services (Moretto \& Ranzato, 2017; Nagendra \& Ostrom, 2014; Ranzato $\&$ Moretto, 2018). Co-produced arrangements in the urban and peri-urban South have a socio-ecological value because they act as polycentric systems of governance, infrastructure and related technology that share existing resources and produce new resources to share (Foster \& Iaione, 2019). The socio-technical perspective, which has mostly addressed emerging alternative infrastructure innovations in the context of growing environmental and economic concerns related to future performance of 
centralized networked systems in the North (van Vliet, 2006, 2012), has been also applied for understanding trajectories of networked and not-networked services in the Global South cities (Furlong, 2014; Jaglin, 2012). In such contexts, co-produced arrangements can be considered as socio-technological innovations that tend to address the shortcomings of centralized systems, possibly in a transitory phase. They require users to 'play an active role in adsorbing, coordinating, and even orchestrating the disruption' (Furlong, 2014, p. 143).

In the second step, we review case-based urban studies to reveal factors related to the spatial dimension. More specifically, the literature survey addresses cases of water and sanitation co-production in urban Asia, Africa and Latin America. The whole reviewed studies, gathered from around 40 papers, embrace a wide range of coproduction solutions. They combine different land entitlements and access to resources, economic dynamics and technological devices adopted at different urban scales. These cases also reflect various local institutional frameworks and different degrees of state/non-state actor collaborations.

\section{Specifying the actor dimension of water and sanitation service co-production}

As a 'heterogeneous umbrella concept' (Nabatchi et al., 2017, p. 769), co-production has a number of definitions within the public governance and management literature. Broadly, co-production is defined as the joint production of urban services by users and public providers, where the former become active asset-holders (Brudney \& England, 1983; Mitlin, 2008; Nabatchi et al., 2017). In general, the 'co' side of co-production refers to a number of involved stakeholders: actors who are agents or representatives of the state (defined as 'regular producers or providers'), who deliver the service with 'professional capacity'; and members of the civil society, or non-state actors, who 
contribute in their capacities as citizens, consumers or clients (also called the 'coproducers') (Nabatchi et al., 2017, p. 769).

Our conceptual framework relies on the working definition of institutionalized co-production for urban services proposed by Joshi and Moore (2004). These authors define institutionalized co-production as 'the provision of public services through a regular long-term relationship between state agencies and organized groups of citizens, where both make substantial resource contributions' (Joshi \& Moore, 2004, p. 40). Accordingly, co-production cannot be understood independently from the role of state agencies. Within this definition, groups of citizens can either be formally recognized or informally organized. The definition implies specific organizational arrangements through which consumers are regularly engaged in the service delivery (Joshi \& Moore, 2004). As such, temporary arrangements are not considered to be genuine coproduction.

Moreover, because WSS service provision can involve multiple stakeholders, our framework will enlarge upon Joshi and Moore's definition by referring to Bovaird (2007, p. 847) who considers co-production as 'the provision of services through regular, long-term relationships between professionalized service providers (in any sector) and service users or other members of the community, where all parties make substantial resource contributions'. This definition includes and recognizes the role of other kind of 'intermediaries': such as volunteers, community groups and NGOs, and private actors, who frequently assume relevant roles in services provision for lowincome households (Bovaird, 2007). This is especially the case in the Global South.

Following from these two definitions, we refer to water and sanitation coproduction as the provision of WSS services through a regular long-term relationship between state actors and lay actors where all three parties-end-users, intermediaries 
and providers - collaborate during some or all of the phases of the service delivery cycle (i.e., planning, design, delivery and assessment). The relationship between these three parties is the lens through which we explore the elements characterizing the actor dimension of WSS service co-production.

Co-production can be applied to all phases of the public service delivery cycle (Moretto \& Ranzato, 2017). Different types of co-production can thereby be distinguished according to the phase of the project in which it occurs.

'Co-planning' involves identification of strategies for urban service delivery that can include participatory budgeting, co-funding and direct involvement of citizens in the decision-making process (Bovaird, 2007; Nabatchi et al., 2017). 'Co-design' refers to joint activities between users and providers related to the structuring of the services (Bovaird \& Loeffler, 2012; Nabatchi et al., 2017). 'Co-delivery' and 'co-management' concern the common provision and maintenance of the service and its infrastructure (Nabatchi et al., 2017). An example is the construction, by community groups, of community toilets, with technical support provided by local authorities and managed and maintained by appointed caretakers (Tomlinson, 2015). Finally, 'co-assessment' refers to joint activities related to monitoring and assessment of the performance and potential improvement of the service (Bovaird \& Loeffler, 2012; Nabatchi et al., 2017).

\section{Involvement of end-users in co-production}

The scale of end-user involvement is a fundamental qualifying element of coproduction. Individuals, groups and collectives may engage in co-production, influencing the size of the co-production activity and the distribution of benefits (Nabatchi et al., 2017). In individual co-production, a state actor and a lay actor, generally a client or a customer, work synergistically to deliver personal benefits for the 
latter (Brudney \& England, 1983; Nabatchi et al., 2017). Drinking water can for instance be supplied through household/compound connections from the main distribution system, based on individual requests to the water agency and an active contribution by the citizen, including capital (e.g., financial payments, materials and technological devices) and in-kind (i.e., time and work-force) contributions (Moretto \& Ranzato, 2017). In group co-production, state actors collaborate with a certain group of lay actors with common goals, as in the case of a group of citizens operating and managing a shared water tap or toilet, co-funded by the local authority (Allen et al., 2017; Moretto et al., 2018). Even if this type of co-production activity leads to personal benefits, it usually also generates 'spillover effects' and social benefits (Nabatchi et al., 2017, p. 770). In collective co-production, defined as 'the joint action of citizens to support public services and achieve outcomes' (Bovaird, Stoker, Jones, Loeffler, \& Pinilla Roncancio, 2016, p. 51), the benefits are enjoyed on a broader communal scale, even if several dynamics may impede their equal distribution (Nabatchi et al., 2017, p. 770). For instance, neighbourhood water networks or decentralized wastewater treatments are usually operated and managed by Water User Associations or private contractors following a market logic (Ali, 2010; Moretto et al., 2018). Publiccommunity and public-private-community partnerships are not exempt from the risk to be unsustainable or unequal, as they place a strong role in the economic and managerial skills and interests of the intermediaries (Dos Santos et al., 2017).

Many studies (Cabrera, 2015; Nabatchi et al., 2017; Ostrom, 2009; van Vliet, 2006) have demonstrated that the role and number of users are crucial factors for the development of co-production practices. Users may be engaged in WSS services in multiple roles (Nabatchi et al., 2017, p. 769): citizen (a community member who takes individual and/or collective action to serve social or environmental goals); client (a 
legitimate recipient of services who is 'not required to directly pay the provider'); customer ('a recipient of public services required to directly pay the provider'). Coproviders are users (citizens, client or customers), usually excluded from large technical systems, who participate actively in any of the phases of the service cycle (van Vliet, 2006). In Global South cities, active participation in WSS co-production usually takes place in the funding, operation and management phases of the delivery process, even if there are cases of early involvement of citizens in the planning of the service (Moretto et al., 2018).

The group size has an impact on the costs of co-production, because the larger the group is, the higher the costs related to self-organization and decision-making processes are (Ostrom, 2009). Larger groups are generally characterized by a 'heterogeneity of interests', which makes the negotiation and organization processes more difficult (Ostrom, 1990, p. 146). However, if the management of a service system is very costly, such as in the case of large water and sanitation networks, a consistent number of users can be better mobilized to deliver the labour and resources needed (Ostrom, 2009).

Ostrom (2009) also stressed that norms and social capital, as well as user motivation/willingness, are important factors to be considered when characterizing coproduction. Socio-economic capacity and availability of time affect users' possibility to participate in co-produced initiatives (van Eijk \& Steen, 2014). Among users of resource systems, mutual trust and shared values originating from existing forms of collaboration can imply lower transaction costs in community-based service provision (Ostrom, 2009, p. 421).

Willingness to participate can descend from individual or pro-social motivations (van Eijk \& Steen, 2014). In the areas not connected to the centralized network, co- 
production may represent the only available solution to access WSS services. In such contexts, motivation to co-produce can simply originate from the individual inhabitants' necessity to satisfy a basic need in the easiest way and shortest time, whatever may be the associated operational costs. Moreover, through appropriate policies and incentives, citizens can be encouraged to devote more time to collective co-production of services (van Eijk \& Steen, 2014). In some cases (Anderies, Janssen \& Ostrom, 2004; Winayanti \& Lang, 2004), communities have been incentivized to develop community services (in water, sanitation and drainage) and to improve their settlements. These incentives included the granting of legal housing titles (Winayanti \& Lang, 2004), subsidised tariffs or involvement in the election of public infrastructure providers (Anderies et al., 2004). The use of such mechanisms might increase participation, prevent free-riding on infrastructure and improve maintenance, thus reducing barriers to successful coproduction (Anderies et al., 2004).

\section{A rich landscape of intermediaries}

Service provision in the Global South follows many paths and includes a variety of intermediary actors in different phases of the delivery cycle, as highlighted in many studies (Allen et al., 2006a, 2006b, 2017; Cabrera, 2015; Verschuere et al., 2012; Moretto \& Ranzato, 2017). Within co-production practices, intermediaries vary in terms of the body in charge and the type of cooperation with state actors.

The private sector can involve diverse actors: large formal companies, mediumsized municipal water firms or informal local vendors (Allen et al., 2006b). The community sector is also characterized by a variety of intermediary actors. A common example, in the Global South cities, is community associations (e.g., Water User Associations, Water Committees) that collaborate in managing water points, improving 
connections and fixing damage to water, sanitation and drainage services (Cabrera, 2015; Joshi \& Moore, 2004; Moretto et al., 2018). These informal or semi-formal providers often become the principle actors responsible for neighbourhood water and sanitation provision (Allen et al., 2017; Cabrera, 2015). Semi-professional civil society organizations, such as third sector or for-profit organizations working with communities, can also be involved as 'mediators' in the service cycle (Verschuere et al, 2012; Moretto \& Ranzato, 2017). That represents the most widespread arrangement in the case of sanitation co-production.

The landscape of community intermediaries is characterized by different degrees of institutionalization. It includes both structured schemes and informal schemes. Formal structured schemes can be authorized by the public sector under a formal regulatory framework and/or assisted by NGOs. In case of water supply from a coproduced system, the need to support administrative, management and technical maintenance activities of the 'intermediary body' often makes the direct costs sustained by users for accessing the service - which include the cost for water unit, inscription fees and the cost of materials for in-house connection - higher than the costs for water unit sustained by the users of the centralized service. The quality of the service standards is often an essential condition for the acceptability of co-produced services, especially when other water supply options are available in the area (Allen et al., 2017; Moretto et al., 2018). In the case of the introduction of decentralized sanitation system in areas not previously served by sewerage, the operational and financial capacity of an intermediary is directly proportional to the mobilization of users, namely their perception of the importance of this service and their desire to contribute. To that end, public authorities and NGOs mostly operate by raising awareness of the inhabitants about health issues and providing subsidies to users, such as preferential tariffs for 
desludging or for in-house connections (Ali, 2010; Parkinson \& Tayler, 2003). Informal schemes are characterized by self-provision activities developed by communities, without any formal status or agreement with the government and local authorities (Allen et al., 2006b). In those cases, water and drainage services, rarely sanitation, are generally provided through community mutual help relationships (Allen et al., 2006a, 2006b; Joshi \& Moore, 2004). The private sector is similarly heterogeneous in its institutionalization, including, for example, private informal or licensed water vendors (Allen et al., 2006a; Cabrera, 2015) and small companies authorized to perform desludging service or install septic tanks (Schramm, 2011).

\section{The role and organization of regular service providers}

Providers can be centralized state authorities or decentralized agencies, delegating tasks (i.e., operation and maintenance) at the local level (Allen et al., 2006a, 2006b; Joshi \& Moore, 2004; Schramm, 2011). If service operation and maintenance can be assigned to specific public or private agencies, the state usually retains the main role for policing and monitoring (Allen et al., 2006b).

Co-production usually occupies the spaces left open by the deficiencies of the centralized system. In water supply, decentralized service co-production can be a pragmatic strategy to guarantying access to water to inhabitants of poorly served areas or to ensuring service in new urban areas. Co-production can therefore comply with a pro-poor approach aimed at fostering participation and citizen engagement or with a commodification policy aimed at reducing state expenditure while promoting marketbased solutions (Jaglin, 2012; Moretto et al., 2018). Service fragmentation can lead to higher direct costs for users than the ones of centralized system (e.g., higher water price/unit, connection cost). Still it has to be stressed that centralized system may lead 
to substantial indirect costs when they are not efficient in terms of sufficient water quantity and quality, frequency and pressure (Ali, 2010; Domenech, 2011; Opryszko, Huang, Soderlund \& Shwab, 2009). These costs include the provision of complementary technology for in-house storage (e.g., underground and/or roof tanks), filtering, pumping and distribution (e.g., filters, booster pumps and tertiary pipes), and eventually the surplus costs for purchasing water from private vendors (e.g. bottled water and/or water from trucks), usually more expensive than municipal water. With respect to sanitation, ensuring public health, environmental protection and service reliability is still making provision of centralized sewerage and wastewater treatment the preferred strategy for infrastructure development in urban areas, as it is generally more effective to treat and monitor effluents from a single generating point than multiple ones. However, developing large-scale centralized systems, in growing cities partially covered or almost lacking sewerage, requires planning capacities and large capital investments that are not readily available in such contexts (Domenech, 2011; Massoud, Tarhini \& Nasr, 2009; Sapkota et al., 2015). Service decentralization may therefore represent a viable option for sanitation, especially in peri-urban areas or neighbourhoods with a high dense urban morphology, although open questions regarding sustainability of decentralized systems remain (Parkinson \& Tayler, 2003). Main challenges are the uncertainty about long-term performance and operation and maintenance costs, the capacity of simple facilities (i.e. septic tank, ponds) to ensure standard purification and hygiene levels, the difficulty to perform professional management of on-site complex technologies, as well as the significant areas of land needed for installing decentralized treatment plants (Massoud et al., 2009; Parkinson \& Tayler, 2003; Sapkota et al., 2015; Wilderer \& Schreff, 2000). 
Service providers can be a composite of different responsible agencies. WSS services can be delivered directly by the public sector, through national agencies established for that purpose. They can also be delegated, through a variety of mechanisms, to other institutions. Different institutional architectures and publicprivate organizational arrangements can be present at the city level. This may result in fragmentation of the service (Lorrain, 2000; Parkinson \& Tayler, 2003), multiple scales of complexity of infrastructure (Allen et al., 2006b) and different power dynamics for safeguarding private interests (Ahlers et al., 2014). Involvement of the private sector in regular water service provision is usually argued on the basis of efficiency and effectiveness, with limited consideration of social equity and environmental sustainability (Allen et al., 2006b). In sanitation, the need of high technical and managerial skills for operating decentralized wastewater treatment system, often implies the involvement of private operators in co-production.

\section{Mediating the service flow through resource and technology}

Moretto and Ranzato (2017) argued that resources and technologies represent primary categories to be considered when analyzing the co-production of water and sanitation services. Studies that have analyzed techno-environmental aspects of conventional service co-production have adopted either a socio-ecological or a sociotechnical perspective. These are expressed through two existing conceptual frameworks proposed, respectively, by Anderies et al. (2004) based on Ostrom (1990), and by Yu, Farrelly and Brown (2011) and Yu, Brown and Morison (2012) based on van Vliet, Chappels and Shove (2005) and van Vliet (2006, 2012).

The socio-ecological perspective considers conventional services as complex systems whose functioning and quality rely on their ecological characteristics, the 
infrastructure solutions employed and the policies and institutions which regulate the management of the territory and related resources (Anderies et al., 2004; Ostrom, 2009).

The conceptual framework developed by Anderies et al. (2004) explains how the characteristics of the resource system, the resource units generated by it, the attributes of the system's users and its governance structure work together to achieve particular outcomes at any time and place. Their framework conceptualizes a socio-ecological system as being composed of four elements: the resource, the resource user, the public infrastructure providers and the public infrastructure. This helps bring together physical and social capitals in a single approach (e.g., engineered works and governing/managing rules). These elements are influenced by external forces (e.g., environmental resource hazards and major political changes), while being intrinsically linked through multiple internal dynamics.

The interrelations between resource users and public infrastructure providers are multiple. In simple systems, the actors may overlap when, for example, resource users form a small group with common interests, operating as both users and infrastructure provider. Complex systems may involve a more structured organization of actors managing the ecosystem at multiple levels (Anderies et al., 2004). The relationship between the resource users and infrastructure providers underpins co-production arrangements and its form may determine the sustainability of a socio-ecological system.

Studies developed in the field of socio-technical services (Hegger \& van Vliet, 2010; van Vliet et al., 2005; van Vliet, 2006, 2012) have mainly focused on understanding technology-behaviour interactions and the role of social actors and citizen-consumers. From a socio-technical perspective, utility services—such as water, waste and electricity—are conceptualized as technological systems linking natural 
resources, providers and consumers. They can assume different configurations: from centralized service provision, where the resource is provided (through a specific technology) by a monopolistic institution/company to citizen-consumers, to a splintered provision system where multiple resources can be associated with different providers using standard and new technologies (van Vliet, 2006; 2012). Van Vliet (2006, 2012) stresses that the sustainability of such innovative service provision implies a differentiation not only of resources, providers and technologies but also of consumer functions, thus recognizing the active role of citizens involved in the daily consumption of the service. Co-production practices are therefore conceptualized as social practices that change the relationship between consumers and providers by modifying the sociotechnical and environmental dynamics of the services. Yu et al. $(2011,2012)$ first applied this conceptualization, as a framework for service co-production, to the design of governance arrangements for decentralized storm water systems in Australia. Figure 2 describes the socio-technical framework (Yu et al., 2012, adapted from van Vliet et al., 2005).

[Figure 2 near here]

The framework describes relationships between elements within a sociotechnical system. Effective user involvement in decentralized water service provision requires context-specific solutions that can be obtained through 'mixes of scales, technologies, payments systems and cultural and institutional structures that are both economically and environmentally sustainable' (Hegger \& van Vliet, 2010 in Yu et al., 2012, p. 2734). The framework highlights how 'the use of alternative sources of water and diverse scales of infrastructure is linking end-users more closely with providers, with the small-scale technology and the water resource' (Yu et al., 2012, p. 2733). 
In this view, the design and governance of co-production is dependent upon the nature of the different providers (both traditional and new) and forms of provision and their links with the multiple ways of involvement of users in the co-production of the same good or service (from citizen to co-provider). An effective 'mix' and/or 'fit' of water production options implies 'the use of diverse resources and/or qualities of water', and - in turn — the combination of various technologies applied at different scales. Technology can assume different physical (e.g., type and connection of devices) and social (e.g., the actors and their expertise) structures and is conceived as a mediator that connects all elements at the functional and the behavioural levels (Yu et al., 2012, p. 2734).

\section{Characterizing the resources}

Both frameworks - the one proposed by Anderies et al. (2004) and the one proposed by Yu et al. (2012)—recognize resource availability as a fundamental element that shapes (and is impacted by) governance arrangements and infrastructural services. The characteristics of the resource system influence the relationships among actors and therefore the possible co-production arrangements. On the other hand, the co-production of WSS services impacts the manner in which resources are processed and ecological systems are preserved.

Yu et al. (2011) highlight the 'diversity' and 'quality' of resources as relevant factors for characterizing the environmental dynamics of co-produced services. WSS service co-production can employ different types of resources, such as surface water, groundwater, rainwater and household wastewater (Allen et al., 2017; Button, 2017; Pilo', 2017). Types of available resource are context-specific and affect local solutions for co-production. As an example, higher groundwater table in urban areas can facilitate 
the use of urban wells as the main technology for co-produced arrangements.

Conversely, pollution of shallow aquifers in high density areas lacking sewerage system is a considerable concern for the sustainability of such wells (Moretto et al., 2018).

Regarding the 'quality' of the resource, the authors refer to the availability and the qualitative features of the resource as channelled by co-production. Water quality, the physical-chemical and biological characteristics of water, depend on multi-scale natural and anthropogenic drivers that determine the various pressures on the resource (e.g., increasing population and urban density; pollution from domestic, industrial and agricultural activities; groundwater salinization; and technological devices employed in the water and sanitation service) (Allen et al., 2017; Falkenmark, 1997). The quantity of water available in a specific area similarly depends on anthropogenic and natural drivers, from local to urban and hydrogeological basin scales (e.g., urban sprawl, growing water demand, soil waterproofing, climate profiles) (Falkenmark, 1997; Milman \& Short, 2008). When co-produced services do not ensure adequate standards of water quality and quantity, it can drive users to fulfil some of their water demands through more expensive supply modalities (such as purchasing bottled water).

Co-production can operate at different scales of the urban water cycle. In decentralized systems, such as urban wells or on-site wastewater treatment, most resources delivered in co-produced systems can be considered 'local' as they are usually extracted, channelled, used and disposed in the proximity of production points. Such a short-flow cycle can provide benefits to inhabitants in terms of service flexibility and enhanced water security due to reduced dependence on shortcomings of external infrastructures (Marlow, Moglia, Cook \& Beale, 2013; Moretto \& Ranzato, 2017). However, the risk to fail in sustainably closing local water cycle due to poor wastewater treatment and lack of control, can strongly jeopardize the relevance of previous benefits 
(Moretto et al., 2018). In co-produced systems connected to the centralized network, such as co-managed secondary water and sewer networks, co-production can entail the direct involvement of users within the urban flow circulatory processes, by collecting, reusing or recycling the water or the wastewater channelled by the service (Moretto \& Ranzato, 2017). Such a closed loop can generate benefits to the city's overall metabolism (Allen et al., 2017; Button, 2017; Pilo', 2017), although the usual imbalance between low provision of sanitation facilities and increasing provision of water sharps the risk of environmental contamination and public health problems at the urban level (Parkinson \& Tayler, 2003). In addition, co-produced services can contribute to, and be affected by hazard phenomena occurring at the local and drainage/hydrogeological basin scale, such as reducing the quality and quantity of surface and ground water due to untreated disposal, uncontrolled groundwater extraction, or flooding (Allen et al., 2017; Moretto et al., 2018). The multi-scalar nature of water resource and the interconnectedness of service components therefore makes the level of operation of coproduction into the urban water cycle, a relevant element for assessing the sustainability of the practice.

With respect to the relationships between the actor/governance arrangements and the ecological/environmental dynamics of services, the framework of Anderies et al. (2004) suggests mechanisms through which institutions and policies, mediated by socio-ecological factors, can generate incentives that enhance a community's ability to solve problems related to the lack of service provision. Similarly, Moretto and Ranzato (2017) argue that the implementation of specific environmental programmes or policies can directly support the development of co-produced services as a strategic action with the specific aim of managing and preserving natural and water resources (see for instance Button, 2017; Pilo', 2017), introducing regulation and control mechanisms of 
on-site wastewater discharges (Massoud et al., 2009; Parkinson \& Tayler, 2003), or regulating resource consumption (see for instance Pilo', 2017; Becker, Naumann, \& Moss, 2017).

Finally, direct involvement in the service provision can foster a closer relation between recipients and resource. In rural areas, user knowledge of the resource is an important factor for the sustainability of community-based initiatives (Anderies et al., 2004; Ostrom, 2009). In fact, in many cases of water and sanitation co-production, users can develop relevant ecological knowledge by directly managing/using the resources that sustain their livelihoods (Ostrom, 2009). With reference to urban contexts, still various studies highlighted how recipients' awareness of the resource quality and of the service dynamics has been an important element in technological development of the co-produced system. It is specially the case of Water User Associations that need to prioritize their investment for the improvements of their secondary networks (Allen et al., 2017; Kyessi, 2005; Moretto \& Ranzato, 2017; Moretto et al., 2018).

\section{Technological elements of co-production}

The framework developed by Yu et al. (2012) specifically integrates a technological dimension into the understanding of co-production in the use of natural resources. It does so by highlighting the role of technology as a mediator between different institutional configurations of users/providers and different resources mobilized in the service. It suggests that the conceptualization of WSS service co-production should include an understanding of how existing resources and technologies mediate the definition of user/provider arrangements and how, conversely, institution and user preferences, involvement and role influence the scale and nature of the technologies adopted for processing natural resources. Consequently, the scale, complexity and 
connectedness of the technology are important factors to be considered for charactering co-production.

The scale of a technology refers to the extent of the physical artefacts involved in the service. It is generally considered as an intrinsic factor of decentralized and hybrid water systems. Service co-production may occur at different scales: from the primary level (e.g., the household) up to more collective levels (e.g., the block or the settlement) (Moretto \& Ranzato, 2017, p. 7). This has consequences for the technical options, which can range from an on-site technological system serving single households (such as a rainwater tank, shared pit latrine), community devices serving a street or a block (such as community well, condominium septic tank or water tank, comanaged secondary water network, community fountain connected to centralized network, neighbourhood drainage system), up to district technological systems serving a settlement or multiple areas of the city (such as drainage facility, simplified sewage system, decentralized wastewater treatment) (Warnken, Johnston, \& Guilding, 2009; Moretto et al., 2018; Yu et al., 2011, 2012).

The complexity of a system is related to the kind of technology used in the service delivery as well as the governance system required to manage it. Technical complexity here refers to 'the level of expertise, the number of actors and/or the size of an organization needed to run it' (Yu et al., 2011, p. 12). Different system scales may imply more complex technical devices and consequent changes in the respective roles of users, intermediaries and providers. Van Vliet et al. (2005) suggest that the size of an organization depends on the scale of the technology. Systems with higher technical complexity usually require larger organizational support, but an inverse relationship is also possible (Yu et al., 2011). 
Connectedness relates to the structure of the technology: both its physical decentralization and its management within a larger socio-technical infrastructure (van Vliet et al., 2005; Yu et al., 2011). Technologies can function as separated stand-alone systems (e.g., community wells, shared pit latrine) or as grid-connected systems that combine with larger infrastructures (e.g., community-based network extensions of centralized piped water systems, local storm water facilities connected to the primary drainage system) (Yu et al., 2011). The structure of the technology can be determined by the 'architecture' of the socio-technological system, distinguishing between distributive systems ('flow from a central node to the user', such as with water) and accumulative systems ('flow from the user to a central node', such as with sanitation/waste and, again, water) (Frantzeskaki \& Loorbach, 2010, p.1295).

The infrastructure portfolio represents another factor to be considered when looking at the environmental and spatial dimensions of co-production practice. It refers to the taxonomy of devices employed in the different stages of the service provision, from resource extraction to treatment, delivery, maintenance and disposal. Technologies mobilized in co-production can emerge as separate systems, through mechanisms of hybridization or by reconfiguration of the conventional networked system (Geels, 2002; Monstadt \& Schramm, 2013; Moretto \& Ranzato, 2017). They can contribute to amelioration of the current conventional system or introduce a further level of complexity in the network (Allen et al., 2017; Moretto \& Ranzato, 2017; Jaglin, 2012). Still complexification of the technological systems can increase management challenges, especially in the case of introduction of new decentralized wastewater treatments (Sapkota et al., 2015; Wilderer \& Schreff, 2000). Available technology for co-production strictly depends on contextual characteristics, such as the urban 
morphology, the distance and/or connection to the centralized networks, as well as the cost of devices and the technical skill of the involved actors (Moretto et al., 2018).

\section{The spatial dimension of co-production}

In addition to the actors and the techno-environmental dimensions, the spatial dimension is the focus of much of the case study literature on co-production practices in the Global South cities. Practice-oriented research is mainly location-based. It usually highlights the role of local factors - actors, resources, practices, representations - in shaping the range of co-production options. Such an approach finds its roots in pathdependence analysis. According to this approach, technologies adopted in the past influence the choice of methods, designs and practices in the present (Walker, 2000). Hence, a close reading of local history, and influencing factors, may help understanding of the later adoption of specific technologies. Analysis of the role of place-based conditions and culture can, therefore, provide better understanding of the governance and techno-environmental arrangements adopted in contemporary co-production practices.

\section{The quality of the service as a question of spatial justice}

A number of studies on WSS service co-production in the Global South cities have highlighted the spatially distributed nature of the quality of the service (Allen et al., 2006b; Jaglin, 2012; Schramm, 2011). In particular, the accessibility, satisfaction of coverage and regularity are important factors when characterizing the spatial dimensions of co-production and for explaining its patterns of development.

The spatial accessibility of WSS services can be disaggregated along two main physical attributes: the distance between users and the water source in the neighbourhood and the density of users (Allen et al., 2006b). In successful cases of 
service co-production, communities were asked to participate in the planning of communal facilities and to identify their locations within the neighbourhood.

Maintenance, for example, was enhanced when the responsible person lived close to the service site (Burra, Patel, \& Kerr, 2003). Economic accessibility is another relevant driver of co-produced arrangements. When co-production of water and/or sanitation facilities takes place, the costs for using, operating and maintaining the services may be more or less competitive than under regular providers (agency, utility) or private vendors (Ali \& Stevens, 2009; Burra et al., 2003; Moretto et al., 2018). It is therefore relevant to compare water and sanitation expenditures between different areas of the city and to compare these expenditures with dwellers incomes and other charges.

Access to water and sanitation services differs in areas located within the same city (Schramm, 2011) according to their location and status (urban, peri-urban, rural), their socio-economic profile and main use. Economic accessibility to water is in many cases highly related to location factors and is a spatial justice issue. Some authors (Jaglin, 2002; Mitlin, 2008) argue that co-production may be regarded as a 'coping' mechanism, selectively developed in deprived areas of the city with low or non-existent public network coverage: a 'network for the poor' solution. On the other hand, coproduction may be viewed as a means to reclaim a right for the city dwellers, in those areas that are not covered by basic services.

In the same vein, the prevalence of waterborne diseases is associated with the quality and accessibility of water and sanitation services (e.g., the common example of disease occurrence in high-density urban areas where pit-latrines are provided near the wells used for water supply). Co-production can be effective in addressing waterassociated public health risks, as it implies direct control of the inhabitants over the quality of the resource, its spatial distribution, the use of diverse sources and the need 
for varied technologies at different scales (Yu et al., 2011; 2012). However, the quality of water distributed by co-production services is not usually monitored nor considered as a 'public responsibility', which adds to health risks in those areas covered by coproduction.

Understanding whether coverage and regularity can be considered satisfactory requires determination of whether the co-produced service is equally distributed, and if certain social groups, especially the most vulnerable, are getting less benefit (Allen et al., 2006b; Cabrera, 2015; Moretto et al., 2018). Different typologies of water use (for drinking, domestic, agricultural or industrial purposes) can influence levels of both demand and supply, thus determining satisfaction with the service coverage and regularity (Milman \& Short, 2008). The level of community satisfaction with conventional forms of service provision, if they exist, may be a driver for development of alternative co-produced options or 'duplication' of conventional services.

All these elements of the category 'service' are related to the quality of the resource flow aspect of co-production practices. Together they identify the crucial spatial dimensions of water and sanitation services.

\section{Land and settlement rights: the hidden side of water and sanitation co-production}

The spatial pattern of human settlements, together with cultural and social factors, is important for understanding the drivers of co-production arrangements in relation to environmental and ecological processes.

Land tenure, land use and environmental risks are elements that have emerged in many studies as key to understanding co-production practices. Regulatory frameworks guiding urban planning can influence access to WSS for the poorest inhabitants, as a settlement identified as not-regular can be denied connection to the legal service supply 
(Allen et al., 2006b, p. 40). As suggested by Allen et al. (2017, p. 35), formally recognized settlements, often through intermediary bodies, have more secure 'access to municipal resources ... to develop their own WSS services', while 'informal settlements have to manage co-production with their own resources' or through the support of local associations, NGOs' or private for-profit groups. Moreover, perception of security of tenure is fundamental in fostering community investment to improve the infrastructure, services and housing of their settlements (Winayanti \& Lang, 2004).

In cities of the Global South, access to land is a pressing concern. Lack of financially available land and housing for the low-income households favour development of slums and informal areas, which are not always recognized by governments and not served by centralized services (UN, 2016b). In this context of unequal urban growth, acute competition for land and pressure from speculators often results in conflict, eviction and resettlement of the poorest communities. In this situation, obtaining legal authority to build infrastructure may be difficult (Bakker, 2003). Institutionalized co-production might hence be hindered in such areas.

Densely populated urban areas are often exposed to multiple hazards that mainly affect the urban poor, who are often settled in areas at risk. As highlighted by Winayanti and Lang (2004), co-production of WSS services has been triggered by mechanisms of community solidarity and self-organization, developed in response to natural hazards.

Finally, the 'settlement' category within the co-production framework can be understood by analysis of urban morphology, especially when one considers path dependence. Urban morphology (plot, street, constructed space, open space) shapes the choices and typologies of WSS service infrastructure solutions (Schramm, 2011). Highdensity neighbourhoods, defined by narrow streets and lack of public space, limit the potential to extended sanitary networks to the household level and therefore may lead to 
the development of clusters of communal toilet blocks as the only feasible solution (Yatmo \& Atmodiwirjo, 2012). Density and housing typologies should be also considered determinants of water and sanitation co-production as they influence the technological systems and devices that can be employed (Schramm, 2011).

The location of the settlement and its topographic features, including proximity to the official centralized network, also influences the accessibility and quality of the resources and the choice of technology to deploy. Along with lack of economic resources, physical conditions (i.e., environmental risk, high altitude, unsuitable settlement morphology, proximity to industrial sites, soil-contamination or large distance to the resource) can contribute to unfeasibility in constructing, operating or maintaining water and sanitation networks. In these cases, communities have to rely on alternative, decentralized solutions, which can be more expensive; as, for example, when the water must be purchased from vendors (Allen et al., 2017).

Finally, the history of the settlement provides information about the level of consolidation of the settlement and related infrastructure. This history may contribute to the robustness and solidarity of relationships between community members. As discussed, technologies and arrangements adopted in co-production services may be framed by previous solutions. For instance, water irrigation networks may have once influenced the network of streets, and this, in turn may determine the distribution of small-scale water networks in the urban settlement (Cabrera, 2015).

[Table 1 near here]

\section{A preliminary application of the framework}

By simultaneously considering the institutional, techno-environmental and spatial dimensions of co-production, the proposed framework highlights the many elements to 
be taken into account when analyzing unorthodox forms of service delivery-such as WSS service co-production (Table 1). In this regard, the framework provides a guideline listing multidisciplinary categories, factors and attributes related to WSS service co-production that can be employed in data collection, treatment and assessment methodologies. However, validity and conceptual robustness of the framework should be tested through multiple case study applications in Global South cities.

A first tentative application of the presented framework was performed to map WSS co-production practices in the cities of Addis Ababa (Ethiopia), Hanoi (Vietnam) and Cochabamba (Bolivia), as a part of an ongoing research project. These cities exhibit a fragmented landscape of water and sanitation services, which characterizes a rapidly urbanizing environment. The framework revealed itself useful for describing the multiple configurations of WSS co-production and their institutional, physical and spatial characteristics (Tables 2, 3, \& 4), emerging in different urban and peri-urban typologies - from slums (kebele housing typology) in Addis Ababa, to Soviet Collective Blocks in Hanoi and basic territorial organizations in Cochabamba. Data were collected through documentation, surveys and semi-structured interviews conducted by the authors between 2016 and 2019.

\section{[Table 2, Table 3 and Table 4 near here]}

The tentative application demonstrated the capacity of the framework to open up for an integrated understanding of the trajectories of WSS co-production practices in relation to multiple institutional, urban and techno-environmental conditions in the three urban typologies. The descriptive nature of the framework allows adopting a nonnormative perspective when looking at different cases of WSS co-production. Through embracing the proposed comprehensive approach, comparative analysis can facilitate the formulation or test of research hypotheses on WSS co-production, by exploring 
relationships between factors and by examining differences and convergences between multiple cases of WSS co-production.

Several relationships between the Actor-Flow-Area dimensions of WSS coproduction emerge from its first application in the three case studies. In urban areas, such as the ones in Addis Ababa and Hanoi, WSS co-production appears as a transitory practice based on a process of adaptation to the shortcomings of the centralized system. This dynamic differs according to the specific type of area, the technical complexity, the user's motivations and their socio-economic capacity. In areas with higher risks of social/technical exclusion, such as in Addis Ababa's slums, co-production develops from the motivation to satisfy individual basic needs at the lowest cost. Co-production may be very basic in these places, involving simple connected (water) or separated (sanitation) infrastructure configurations, shared by small groups of inhabitants. In collective areas like Hanoi Soviet Blocks, co-production arises from the individual need to fill the gap in accessing the centralized network through simple complementary lowtech devices (water tanks) or as a part of a successive process of spatial and social consolidation, mainly guided by the state (sanitation).

In both areas, a low-tech water service co-production is developing in the last phase of the service cycle (operation and maintenance). It is associated with a centralized form of government of the infrastructure and formally institutionalized public-community intermediaries. New urban development implying a more waterdemanding infrastructure (e.g., from poor-flush to normal-flush), changing neighborhood inhabitants (e.g., densification, increasing in renting, resettlement process, different socio-economic characteristics) and environmental constrains may easily lead to break the ties of group co-production. In such areas, a transition from 
group to individual co-production may emerge as a recurrent dynamic, especially in water supply.

In peripheral areas not connected to the centralized network, such as peri-urban OTBs in Cochabamba, co-production emerges during the mere creation of the neighborhood. In these conditions, the urban morphology, the technological complexity, the social capital and the system of governance of the co-produced practice are closely interwoven. Low urban density and the need to ensure a service from scratch favors forms of users' self-organization, characterized by pro-social motivation and strong community links. If successful, co-production may therefore follow a process of subsequent recognition by the state, a bottom-up institutionalization where the intermediaries demonstrate a close relation with users. A directly proportional relationship between social capital and technological complexity can take shape in this perspective. Unlike the other two cases, the co-production configuration in Cochabamba is associated with a good user's knowledge of the 'qualities' of resource. As in many cases of community-based initiatives in rural areas, user's learning process appears in the need to introduce collective control mechanisms to cope with a declining quantity of underground water.

In all cases, future sustainability of water supply co-production is related with resource boundary conditions that may change in terms of quantity (surface and ground water in Addis, groundwater in Cochabamba) and quality (water contamination in Hanoi) along with the urbanization processes, thus influencing regularity and satisfaction of coverage of the centralized service sustaining grid-connected systems, and the 'local' resource in case of decentralized ones. Such changes imply the need for users to define adaptive strategies that can emerge at different technological scales (households, community), with the enlargement of the infrastructure portfolio (e.g., 
purchase of water tanks and/or filters) or with the introduction of regulatory norms. Hence, the material properties of water (quantity, quality) directly affect the type of social relationship and the technical system employed in co-production, sometimes contributing to reinforcing co-production arrangements (as in the case of Cochabamba), sometimes limiting them (as in the case of Addis Ababa and Hanoi). In the case of decentralized systems and forms of infrastructure management, technological integration can occur following regulations on the use of the resource that are shared by users. In grid-connected systems and centralized forms of infrastructure management, technological integration mostly takes place as a form of individual adaptation. At both individual and collective levels, technological integration seems contributing to the reconfiguration of urban spaces, through occupying, modifying or enlarging both public and private areas. However, questions of equity can emerge when certain type of technology is exclusionary for groups of people lacking the economic resources to cope with the changes in resource characteristics.

When looking at sanitation, the cases confirm that the closure of service water cycle is a significant challenge for co-production. In both Addis Ababa and Hanoi, coproduction doesn't ensure a proper wastewater management, contributing to enhance environmental and public health risks at local and urban level. Co-production of sanitation services often tends to fail to guarantee sustainability when there is a lack of a strong public contribution (for instance, through subsidies, environmental programs, control procedures or awareness raising). This is mostly due to lack of users' motivations to co-produce and little willingness to pay, as well as poor cost recovery from operation of wastewater systems.

With respect to the limits of the framework, the preliminary application in the three cases demonstrated some challenges mainly related with specific urban contexts. 
Some factors - such as Norms and social capital, End-users motivation, Knowledge of the resource, "Qualities" of resource, Land use - are difficult to be assessed, due to lack of reliable information or data accessibility. This could reduce the understanding of some aspects of co-production and therefore the breadth of the research. This shortcoming is also related with the research method employed for developing the framework. In fact, referring to theories on co-production that are built without specifically addressing the peculiarities of the urban environments of the Global South, can lead to partial recognition of the significance of some factors. This limitation can hide an underestimation of aspects of co-production that could be fundamental for the cities of the South, such as issues related to policies and politics, power relations, market completion and costs of different forms of WSS co-produced services with respect to centralized ones.

\section{Conclusions}

Developing strategies to increase people' access to water and sanitation in the cities of the Global South is extremely important for ensuring the achievement of sustainability objectives. Accordingly, the interest on the practice of service co-production is growing at both the levels of scientific research and development cooperation. The objective of the proposed framework is to contribute to filling the gap that public management and urban studies have left in conceptualizing conventional service co-production, particularly for the urban built environments of the Global South.

The literature review and the primary application of the framework in three cases shows how differences and convergences in WSS co-production can be only understood by embracing a comprehensive perspective that includes managerial, techno-environmental and spatial dimensions. This comprehensive analytical 
framework allows highlighting interrelated elements of the co-produced practice that may otherwise be overlooked when observing the practice from a specific perspective. It therefore enables better understanding of the idea of WSS co-production in the cities of the Global South.

Primary applications in the case studies has highlighted how the use of the framework has enabled easier data systematization, despite the difficulties in collecting specific data on WSS, emerged in the case contexts. The framework has allowed for synthesis of multiple forms of information (i.e., qualitative, quantitative, cartographic), demonstrating the possibility of integration between different analytical methods. Such framework's capacities have allowed to quickly obtain a comprehensive and structured overview of the elements of WSS co-production in the three cases, thus permitting to explore the trajectories of co-production in the case contexts in a comparative way. The framework has therefore revealed its main utility in facilitating comparative analysis with the purpose of identifying and testing potential research hypothesis regarding interrelations between factors of WSS co-production and urban, techno-environmental and institutional conditions and processes occurring in the case studies.

Anyway, additional research must be developed for improving the comprehension of some categories/factors and test their validity, as well as for identifying other potentially relevant factors. In particular, the study of the economic dimension of WSS co-production would deserve further research. This is specially the case since the tariff/price of the service does not always reflect the full direct and indirect costs of the practice. Multiple action-oriented applications in different cities of the Global South, as well as theory building from practice, can sustain this purpose, along with the development of a comprehensive state of the art regarding service coproduction in Global South cities. 
In addition, further theoretical and empirical research needs to focus on interrelations between the framework factors in specific contexts/cities. This includes determination of the ways in which governance arrangements and the technical system employed in service co-production mutually influence each another, including questions of technological adaptability and differences between water services and sanitation ones. The interrelations between settlement location, characteristics and proximity to the conventional network, the technology employed and the stakeholders configurations (infrastructural and governance systems) may be revealed by comparative research, leading to a better understanding of the evolution of co-production practices in cities of the Global South. Moreover, understanding how the interrelations between the different categories and factors are influencing the procedural and outcome sustainability of the services delivered in specific contexts, is another question deserving attention.

\section{Declaration of conflicting interest}

The authors declare that there is no conflict of interest

\section{References}

Ahlers, R., Cleaver, F., Rusca, M. \& Schwartz, K. (2014). Informal space in the urban waterscape: Disaggregation and co-production of water services. Water Alternatives 7(1), 1-14.

Ali, M., \& Stevens, L. (2009). Integrated approaches to promoting sanitation: A case study of Faridpur, Bangladesh. Desalination, 248(1), 1-7.

Ali, S. I. (2010). Alternatives for safe water provision in urban and peri-urban slums. Journal of Water and Health, 8(4), 720-734.

Allen, A. (2010). Neither Rural nor Urban: Service Delivery Options That Work for the Peri-urban Poor. In M. Kurian \& P. McCarney (Eds.), Peri-urban Water and Sanitation Services (pp. 27-61). Dordrecht: Springer. 
Allen, A. (2013). Water provision for and by the peri-urban poor. Public-community partnerships or citizens coproduction?. In J. Vojnovic (Ed.), Urban sustainability: A global perspective (pp. 309-340). East Lansing, MI: Michigan State University Press.

Allen, A., Davila, J. D. \& Hofmann, P. (2006a). The peri-urban water poor: Citizens or consumers?. Environment and Urbanization, 18(2), 333-351.

Allen, A., Davila, J. D. \& Hofmann, P. (2006b). Governance of water and sanitation services for the peri-urban poor. London: The Development Planning Unit, University College London.

Allen, A., Hofmann, P., Mukherjee, J. \& Walnycki, A. (2017). Water trajectories through non-networked infrastructure: Insights from peri-urban Dar es Salaam, Cochabamba and Kolkata. Urban Research \& Practice, 10(1), 22-42.

Anderies, J. M., Janssen, M. A. \& Ostrom, E. (2004). A framework to analyze the robustness of social ecological systems from an institutional perspective. Ecology and Society, 9(1), 18, http://www.ecologyandsociety.org/vo19/iss1/art18.

Andreasen, M. H. \& Møller-Jensen, L. (2016). Beyond the networks: Self-help services and post settlement network extensions in the periphery of Dar es Salaam. Habitat International, 53, 39-47.

Bakker, K. (2003). Archipelagos and networks: urbanization and water privatization in the South. The Geographical Journal, 169(4), 328-341.

Bakker, K., Kooy, M., Shofiani, N. E., \& Martijn, E.-J. (2008). Governance Failure: Rethinking the Institutional Dimensions of Urban Water Supply to Poor Households. World Development, 36(10), 1891-1915.

Bates, S. R. \& Smith, N. J. (2008). Understanding change in political science: On the need to bring space into theoretical positions and empirical analyses. Political Studies Review, 6, 175-98.

Becker, S., Naumann, N. \& Moss, T. (2017). Between coproduction and commons: Understanding initiatives to reclaim urban energy provision in Berlin and Hamburg. Urban Research \& Practice, 10(1), 63-85.

Bovaird, T. (2007). Beyond engagement and participation: User and community coproduction of public services. Public Administration Review, 67(5), 846-860. 
Bovaird, T., \& Loeffler, E. (2012). From engagement to co-production: The contribution of users and communities to outcomes and public value. VOLUNTAS: International Journal of Voluntary and Nonprofit Organizations, 23(4), 1119-1138.

Bovaird, T., Stoker, G., Jones, T., Loeffler, E. \& Pinilla Roncancio, M. 2016. Activating collective co-production of public services: Influencing citizens to participate in complex governance mechanisms in the UK. International Review of Administrative Sciences, 82(1), 47-68.

Brudney, J. L. \& England, R. E. (1983). Towards a definition of the coproduction concept. Public Administration Review, 43(1), 59-65.

Burra, S., Patel, S. \& Kerr, T. (2003). Community-designed, built and managed toilet blocks in Indian cities. Environment and Urbanization, 15(2), 11-32.

Button, C. (2017). The co-production of a constant water supply in Mumbai's middle class apartments. Urban Research \& Practice, 10(1), 102-119.

Cabrera, J. E. (2015). Fragmentation urbaine à travers les réseaux techniques [Urban fragmentation across technical networks] (Doctoral Dissertation). Retrieved from https://orbi.ulg.ac.be/handle/2268/180007.

Cepiku, D. \& Giordano, F. (2014). Co-Production in Developing Countries: Insights from the community health workers experience, Public Management Review, 16(3), 317-340.

Coutard, O. (2008). Placing splintering urbanism: Introduction. Geoforum, 39, 18151820.

Coutard, O. \& Rutherford, J. (Eds.). (2015). Beyond the networked city: Infrastructure reconfigurations and urban change in the North and South. London: Routledge.

De, I. \& Nag, T. (2016). Dangers of Decentralisation in Urban Slums: A Comparative Study of Water Supply and Drainage Service Delivery in Kolkata, India. Development Policy Review, 34(2), 253-276.

Dill, B. (2010). Public-public partnerships in urban water provision: the case of Dar es Salaam. Journal of International Development, 22, 611-624.

Domenech, L. (2011). Rethinking water management: From centralised to decentralised water supply and sanitation models. Documents d'Anàlisi Geogràfica, 57(2), 293-310. 
Dos Santos, S., Adams, E. A., Neville, G. Wada, Y., de Sherbinin, A., Mullin Bernhardt, E. \& Adamo, S. B. (2017). Urban growth and water access in subSaharan Africa: Progress, challenges, and emerging research directions. Science of the Total Environment, 607-608, 497-508.

Falkenmark, M. (1997). Society's interaction with the water cycle: A conceptual framework for a more holistic approach. Hydrological Sciences Journal, 42(4), 451-466.

Fernández-Maldonado, A. N. (2008). Expanding networks for the urban poor: Water and telecommunications services in Lima, Peru. Geoforum, 39, 1884-1896.

Foster, S. R. \& Iaione, C. (2019). Ostrom in the City: Design Principles and Practices for the Urban Commons. In D. Cole, B. Hudson \& J. Rosenbloom (Eds.), Routledge Handbook of the Study of the Commons (pp. 235-255). Abingdon: Routledge.

Frantzeskaki, N., \& Loorbach, D. (2010). Towards governing infrasystem transitions. Reinforcing lock-in or facilitating change?. Technological Forecasting \& Social Change, 77, 1292-1301.

Furlong, K. (2014). STS beyond the "modern infrastructure ideal": Extending theory by engaging with infrastructure challenges in the South. Technology in Society, 38, 139-147.

Geels, F. W. (2002). Technological transitions as evolutionary reconfiguration processes: A multi-level perspective and a case-study. Research Policy, 31, $1257-1274$.

Graham, S. \& Marvin, S. (2001). Splintering urbanism: Networked infrastructures, technological mobilities and the urban condition. London: Routledge.

Hegger, D. \& van Vliet, B. (2010). End user perspectives on the transformation of sanitary systems. In B. van Vliet, G. Spaargaren \& P. Oosterveer (Eds.), Social perspectives on the sanitation challenge (pp. 203-216). Dordrecht: Springer.

Heynen, N., Kaika, M. \& Swyngedouw, E. (2006). Urban political ecology: Politicizing the production of urban natures. In N. Heynen, M. Kaika \& E. Swyngedouw (Eds.), The nature of cities: Urban political ecology and the politics of urban metabolism (pp. 1-20). London: Routledge. 
Jaglin, S. (2002). The right to water versus cost recovery: Participation, urban water supply and the poor in sub-Saharan Africa. Environment\&Urbanization, 14(1), 231-245.

Jaglin, S. (2008). Differentiating networked services in Cape Town: Echoes of splintering urbanism?. Geoforum, 39, 1897-1906.

Jaglin, S. (2012). Networked services and features of African urbanization: Other path toward globalization. L'espace Geographique, 41(1), 51-67.

Joshi, A. \& Moore, M. (2004). Institutionalised co-production: unorthodox public service delivery in challenging environments. Journal of Development Studies, 40(4), 31-49.

Katsongo, K. (2012). Partnership modalities for the management of drinking water in poor urban neighbourhoods: The example of Kinshasa, Democratic Republic of Congo. In M. Robertson (Ed.), Sustainable cities: Local solutions in the Global South (pp. 113-132). Ottawa: Practical Action Publishing.

Kjellen, M. (2000). Complementary Water Systems in Dar es Salaam, Tanzania: The Case of Water Vending. Water Resources Development, 16(1), 143-154.

Kyessi, A. G. (2005). Community-based urban water management in fringe neighbourhoods: the case of Dar es Salaam, Tanzania. Habitat International, 29, $1-25$.

Kooy, M. \& Bakker, K. (2008). Splintered networks: The colonial and contemporary waters of Jakarta. Geoforum, 39, 1843-1858.

Lorrain, D. (2000). Gouverner les villes. Questions pour un agenda de recherche [Governing the cities. Questions for a research agenda]. Pôle Sud, 13, 27-40.

Marlow, D. R., Moglia, M., Cook, S. \& Beale, D. J. (2013). Towards sustainable urban water management: A critical reassessment. Water Research, 47, 7150-7161.

Massoud, M. A. Tarhini, A. \& Nasr, J. A. (2009). Decentralized approaches to wastewater treatment and management: Applicability in developing countries. Journal of Environmental Management, 90, 652-659.

McGranahan, G. (2013). Community-driven sanitation improvement in deprived urban neighbourhoods: Meeting the challenges of local collective action, coproduction, affordability and a trans-sectoral approach (Research Report). London: SHARE - London School of Hygiene and Tropical Medicine. 
McMillan, R., Spronk, S. \& Caswell, C. (2014). Popular participation, equity, and coproduction of water and sanitation services in Caracas, Venezuela. Water International, 39(2), 201-215.

Miles, M. B. \& Huberman A. M. (1994). Qualitative data analysis: An expanded sourcebook. Thousand Oaks: Sage Publications.

Milman, A., \& Short, A. (2008). Incorporating resilience into sustainability indicators: An example for the urban water sector. Global Environmental Change, 18, 758767.

Mitlin, D., \& Satterthwaite, D. (2013). Urban Poverty in the Global South: Scale and Nature. Abington: Routledge.

Mitlin, D. (2008). With and beyond the state -- Co-production as a route to political influence, power and transformation for grassroots organizations. Environment\&Urbanization, 20(2), 339-360.

Monstadt, J. (2009). Conceptualizing the political ecology of urban infrastructures: Insights from technology and urban studies. Environment and Planning A, 41, 1924-1942.

Monstadt, J. \& Schramm, S. (2013). Beyond the networked city? Suburban constellations in water and sanitation systems. In R. Keil (Ed.), Suburban constellations (pp. 85-94). Berlin: Jovis.

Moretto, L. (2010). Coproduction du service d'eau et recomposition de l'espace intraurbain dans la périphérie sud de Caracas [Coproduction of water service and recomposition of the intra-urban space in the southern suburbs of Caracas]. Espaces et sociétés, 143, 81-99.

Moretto, L., \& Ranzato, M. (2017). A socio-natural standpoint to understand coproduction of water, energy and waste services. Urban Research and Practice, 10(1), 1-21.

Moretto, L., Faldi, G., Ranzato, M., Rosati, F. N., Ilito Boozi, J.-P. \& Teller, J. (2018). Challenges of water and sanitation service co-production in the global South. Environment and Urbanization, 30(2), 425-443.

Nabatchi, T., Sancino, A. \& Sicilia, M. (2017). Varieties of participation in public services: The who, when, and what of coproduction. Public Administration Review, 77, 766-776. 
Nagendra, H. \& Ostrom, E. (2014). Applying the social-ecological system framework to the diagnosis of urban lake commons in Bangalore, India. Ecology and Society, 19(2), 67, https://www.ecologyandsociety.org/vol19/iss2/art67/

Onwuegbuzie, A. J. \& Weinbaum, R. (2017). A Framework for Using Qualitative Comparative Analysis for the Review of the Literature. The Qualitative Report, 22(2), 359-372.

Opryszko, M. C., Huang, H., Soderlund, K. \& Schwab, K. J. (2009). Data gaps in evidence-based research on small water enterprises in developing countries. Journal of Water and Health, 7(4), 609-622.

Osborne, S. P. \& Strokosch. K. (2013). It takes two to tango? Understanding the coproduction of public services by integrating the services management and public administration perspectives. British Journal of Management, 24, S31-S47.

Ostrom, E. (1990). Governing the commons. The evolution of institutions for collective action. New York: Cambridge University Press.

Ostrom, E. (1996). Crossing the great divide: Coproduction, synergy, and development. World Development, 24(6), 1073-1087.

Ostrom, E. (2009). A general framework for analyzing sustainability of socialecological systems. Science, 325, 419-422.

Parkinson, J. \& Tayler, K. (2003). Decentralized wastewater management in peri-urban areas in low-income countries. Environment\&Urbanization, 15(1), 75-90.

Parks, R. B., Baker, P. C., Kiser, L., Oakerson, R., Ostrom, E., Ostrom, V., ... Wilson, R. (1981). Consumers as coproducers of public services: Some economic and institutional considerations. Policy Studies Journal, 9(7), 1001-1011.

Pestoff, V., Brandsen, T. \& Verschuere, B. (Eds.). (2012). New public governance, the third sector and co-production. London: Routledge.

Pilo', F. (2017). 'Co-producing affordability to the electricity service': A marketoriented response to addressing inequality of access in Rio de Janeiro's favelas. Urban Research \& Practice, 10(1), 86-101.

Pflieger, G. \& Matthieussent, S. (2008). Water and power in Santiago de Chile: Sociospatial segregation through network integration. Geoforum, 39, 1907-1921.

Pugh, J. (2009). What are the consequences of the 'spatial turn' for how we understand politics today? A proposed research agenda. Progress in Human Geography, 33(5), 579-586. 
Ranzato, M., \& Moretto, L. (2018). Co-production and the environment. In T.

Brandsen, T. Steen \& B. Verschuere (Eds.), Co-production and co-creation (pp. 180-190). Oxford: Taylor and Francis.

Rihoux, B. \& Lobe, B. (2009). The case for qualitative comparative analysis (QCA): Adding leverage for thick cross-case comparison. In D.S. Byrne \& C.C. Ragin (Eds.), The Sage handbook of case-based methods (pp. 222-242). London: Sage.

Ritchie, J. \& Lewis, J. (Eds.) (2003). Qualitative Research Practice. A Guide for Social Science Students and Researchers. London: SAGE Publications.

Robertson, M. (Ed.). (2012). Sustainable cities. Ottawa: Practical Action Publishing. Sapkota, M., Arora, M., Malano, H., Moglia, M., Sharma, A., George, B. \& Pamminger, F. (2015). An Overview of Hybrid Water Supply Systems in the Context of Urban Water Management: Challenges and Opportunities. Water, 7, 153-174. Schramm, S. (2011). Semicentralised water supply and treatment: Options for the dynamic urban area of Hanoi, Vietnam. Journal of Environmental Assessment Policy and Management, 13(2), 285-314.

Tomlinson, R. (2015). Scalable community-led Slum upgrading: The Indian alliance and community toilet blocks in Pune and Mumbai. Habitat International, 50, $160-168$.

United Nations Human Settlements Programme. (2016). Urbanization and development: emerging futures. World cities report 2016. Nairobi: UN-Habitat

United Nations World Water Assessment Programme. (2015). The United Nations World Water Development Report 2015: Water for a sustainable world. Paris: UNESCO.

United Nations. (2016a, February 29). Habitat III Policy Paper 9 - Urban services and technology [pdf]. Retrieved from http://habitat3.org/wp-content/uploads/PU9HABITAT-III-POLICY-PAPER.pdf

United Nations. (2016b). Habitat III Issue Papers [pdf]. Retrieved from http://habitat3.org/wp-content/uploads/Habitat-III-Issue-Papers-report.pdf

van Eijk, C. \& Steen, T. (2014). Why people co-produce: Analysing citizens' perceptions on co-planning engagement in health care services. Public Management Review 16(3), 358-382. 
van Vliet, B. (2006). Citizen-consumer roles in environmental management of large technological systems. In P.-P.-P. Verbeek \& A. Slob (Eds.), User behavior and technology development (pp. 309-318). Dordrecht: Springer.

van Vliet, B. (2012). Sustainable innovation in network-bound systems: Implications for the consumption of water, wastewater and electricity Services. Journal of Environmental Policy \& Planning, 14(3), 263-278.

van Vliet, B., Chappels, H. \& Shove, E. (2005). Infrastructure of consumption: Environmental innovations in the utility of industries. London: Earthscan.

Verschuere, B., Brandsen, T. \& Pestoff, V. (2012). Co-production: The state of the art in research and the future agenda. VOLUNTAS: International Journal of Voluntary and Nonprofit Organizations, 23(4), 1083-1101.

Walker, R. (2001). The geography of production. In E. Sheppard \& T. Barnes (Eds.), A companion to economic geography (pp. 113-132). Oxford: Blackwell.

Warnken, J., Johnston, N. \& Guilding, C. (2009). Exploring the regulatory framework and governance of decentralised water management systems: A strata and community title perspective (Waterlines Report Series No 19). Canberra: Commonwealth of Australia.

Wilderer, P. A. \& Schreff, D. (2000). Decentralized and centralized wastewater management: a challenge for technology developers. Water Science and Technology, 41(1), 1-8.

Winayanti, L., \& Lang, H. C. (2004). Provision of urban services in an informal settlement: A Case study of Kampung Penas Tanggul, Jakarta. Habitat International 28(1), 41-65.

World Health Organization / United Nations International Children's Emergency Fund. (2015). WHO/UNICEF Joint Monitoring Programme for Water Supply, Sanitation and Hygiene [Dataset]. Retrieved from: https://washdata.org/data Yatmo, Y. A. \& Atmodiwirjo, P. (2012). Communal toilet as a collective spatial system in high Density urban Kampung. Procedia - Social and Behavioral Sciences, 36, $677-687$.

Yu, C., Farrelly, M. \& Brown, R. (2011). Co-production and the governance of decentralised stormwater systems (Report for The Centre for Water Sensitive Cities). Clayton: Monash University. 
Yu, C., Brown, R. \& Morison, P. (2012). Co-governing decentralised water systems: An analytical framework. Water Science and Technology, 66(12), 2731-2736.

Zérah, M.-H. (2008). Splintering urbanism in Mumbai: Contrasting trends in a multilayered society. Geoforum, 39, 1922-1932. 
Table 1. Dimensions, categories, factors and attributes of the actor-flow-area framework

\begin{tabular}{|c|c|c|c|c|}
\hline Dimensions & Categories & Factors & Attributes & References \\
\hline \multirow{10}{*}{ Actors } & \multirow{6}{*}{ Users } & Level of co-production & $\begin{array}{l}\text { Co-planning, co-design, co- } \\
\text { delivery, co-assessment }\end{array}$ & $\begin{array}{l}\text { Bovaird, 2007; Bovaird \& Loeffler, } \\
\text { 2012; Tomlinson, 2015; Nabatchi et } \\
\text { al., } 2017\end{array}$ \\
\hline & & $\begin{array}{l}\text { Users' scale of } \\
\text { involvement }\end{array}$ & Collective, group, individuals & $\begin{array}{l}\text { Brudney \& England, 1983; Ali, } \\
\text { 2010; Bovaird et al., 2016; Moretto } \\
\text { \& Ranzato, 2017; Nabatchi et al., } \\
\text { 2017; Dos Santos et al., 2017; Allen } \\
\text { et al., 2017; Moretto et al., 2018 }\end{array}$ \\
\hline & & Role of users & Citizens, clients, consumers & $\begin{array}{l}\text { Van Vliet, 2006; Nabatchi et al., } \\
\text { 2017; Moretto et al., } 2018\end{array}$ \\
\hline & & Number of users & Small group, large group & Ostrom, 2009; Cabrera, 2015 \\
\hline & & $\begin{array}{l}\text { End-users motivation / } \\
\text { willingness }\end{array}$ & $\begin{array}{l}\text { Individual, pro-social / type } \\
\text { of incentives: economic, } \\
\text { political, social, spatial }\end{array}$ & $\begin{array}{l}\text { Anderies et al., 2004; Winayanti \& } \\
\text { Lang, 2004; Ostrom, 2009; Van } \\
\text { Eijk \& Steen, } 2014\end{array}$ \\
\hline & & $\begin{array}{l}\text { Norms and social } \\
\text { capital }\end{array}$ & $\begin{array}{l}\text { Socio-economic capacity, } \\
\text { availability of time / existing } \\
\text { forms of collaboration and } \\
\text { shared values }\end{array}$ & $\begin{array}{l}\text { Anderies et al., 2004; Mitlin, 2008; } \\
\text { Ostrom, 2009; McMillan et al., } \\
2014\end{array}$ \\
\hline & \multirow{2}{*}{ Intermediaries } & $\begin{array}{l}\text { Bodies in charge and } \\
\text { type }\end{array}$ & $\begin{array}{l}\text { Public, private, community } \\
\text { association, third sector, for- } \\
\text { profit organisations, public- } \\
\text { private-community } \\
\text { organization }\end{array}$ & $\begin{array}{l}\text { Joshi \& Moore, 2004; Allen et al., } \\
\text { 2006a, 2006b, 2017; Verschuere et } \\
\text { al., 2012; Cabrera, 2015; Moretto } \\
\text { \& Ranzato, } 2017\end{array}$ \\
\hline & & $\begin{array}{l}\text { Degree of } \\
\text { institutionalization }\end{array}$ & $\begin{array}{l}\text { Formal, informal, semi- } \\
\text { formal }\end{array}$ & $\begin{array}{l}\text { Parkinson \& Tayler, 2003; Joshi \& } \\
\text { Moore, 2004; Allen et al., 2006a, } \\
\text { 2006b, 2017; Ali, 2010;Schramm, } \\
\text { 2011; Cabrera, 2015; Moretto \& } \\
\text { Ranzato, 2017; Moretto et al., } 2018\end{array}$ \\
\hline & \multirow[t]{2}{*}{ Providers } & Form of government & Centralized, decentralized & $\begin{array}{l}\text { Wilderer \& Schreff; 2000; } \\
\text { Parkinson \& Tayler, 2003; Joshi \& } \\
\text { Moore, 2004; Allen et al., 2006a, } \\
\text { 2006b; Ostrom,, 2009; Massoud et } \\
\text { al., 2009; Schramm, 2011; Jaglin, } \\
\text { 2012; Moretto \& Ranzato, 2017; } \\
\text { Moretto et a., } 2018\end{array}$ \\
\hline & & $\begin{array}{l}\text { Responsible agency } \\
\text { and type }\end{array}$ & Public, private, public-private & $\begin{array}{l}\text { Lorrain, 2000; Parkinson \& Tayler, } \\
\text { 2003; Allen et al., 2006b; Ahlers et } \\
\text { al., } 2014\end{array}$ \\
\hline \multirow{9}{*}{ Flows } & \multirow{5}{*}{ Resources } & $\begin{array}{l}\text { Diversity of the } \\
\text { resource }\end{array}$ & $\begin{array}{l}\text { Groundwater, surface water } \\
\text { rainwater, wastewater }\end{array}$ & $\begin{array}{l}\text { Falkenmark, 1997; Yu et al., 2011, } \\
\text { 2012; Button, 2017; Allen et al., } \\
\text { 2017; Pilo' 2017; Moretto et al., } \\
2018\end{array}$ \\
\hline & & $\begin{array}{l}\text { "Qualities" of } \\
\text { resource }\end{array}$ & Quality, quantity & $\begin{array}{l}\text { Falkenmark, 1997; Milman \& } \\
\text { Short, 2008; Yu et al., 2011, 2012; } \\
\text { Allen et al., } 2017\end{array}$ \\
\hline & & $\begin{array}{l}\text { Scale of urban water } \\
\text { cycle }\end{array}$ & Local scale, city scale & $\begin{array}{l}\text { Parkinson \& Tayler, 2003; Marlow } \\
\text { et al., 2013; Button, 2017; Allen et } \\
\text { al., 2017; Pilo', 2017; Moretto \& } \\
\text { Ranzato, 2017; Moretto et al., } 2018\end{array}$ \\
\hline & & $\begin{array}{l}\text { Environmental } \\
\text { programmes / policies }\end{array}$ & $\mathrm{Y} / \mathrm{N}$ & $\begin{array}{l}\text { Anderies et al., 2004; Parkinson \& } \\
\text { Tayler, 2003; Massoud et al., 2009; } \\
\text { Button, 2017; Pilo', 2017; Becker et } \\
\text { al., 2017; Moretto \& Ranzato, } 2017\end{array}$ \\
\hline & & $\begin{array}{l}\text { Awareness of resource } \\
\text { dynamics }\end{array}$ & $\mathrm{Y} / \mathrm{N}$ & $\begin{array}{l}\text { Moretto, 2010; Anderies et al., } \\
\text { 2004; Ostrom, 2009; Kyessi, 2005; } \\
\text { Moretto \& Ranzato, 2017; Moretto } \\
\text { et al., } 2018\end{array}$ \\
\hline & \multirow{4}{*}{ Technology } & Scale of technology & $\begin{array}{l}\text { Households, } \\
\text { community/block/street level, } \\
\text { settlement/district level }\end{array}$ & $\begin{array}{l}\text { Warnken et al., } 2009 \text {; Yu et al., } \\
\text { 2011, 2012; Moretto \& Ranzato, } \\
2017\end{array}$ \\
\hline & & Technical complexity & $\begin{array}{l}\text { Level of expertise, number of } \\
\text { actors and/or the size of an } \\
\text { organisation, kind of } \\
\text { technology }\end{array}$ & $\begin{array}{l}\text { Van Vliet et al., } 2005 \text {; Yu et al., } \\
2011\end{array}$ \\
\hline & & Connectedness & $\begin{array}{l}\text { Combined vs. separated } \\
\text { systems, distributive vs. } \\
\text { accumulative }\end{array}$ & $\begin{array}{l}\text { Van Vliet et al., 2005; Yu et al., } \\
\text { 2011; Frantzeskaki \& Loorbach, } \\
2010\end{array}$ \\
\hline & & Infrastructure portfolio & $\begin{array}{l}\text { Taxonomy of devices, } \\
\text { technology availability, } \\
\text { device's interface operability }\end{array}$ & $\begin{array}{l}\text { Wilderer \& Schreff, 2000; Jaglin, } \\
\text { 2012; Monstadt \& Schramm, 2013; } \\
\text { Sapkota et al., 2015; Allen et al., } \\
\text { 2017; Moretto \& Ranzato, 2017; } \\
\text { Moretto et al., } 2018\end{array}$ \\
\hline
\end{tabular}




\begin{tabular}{|c|c|c|c|c|}
\hline \multirow{10}{*}{ Areas } & \multirow{4}{*}{ Service } & Accessibility & Physical, economic, social & $\begin{array}{l}\text { Jaglin, 2002; Burra et al., 2003; } \\
\text { Allen et al., 2006b; Mitlin, 2008; } \\
\text { Ali \& Stevens, 2009; Schramm, } \\
\text { 2011; Moretto et al., } 2018\end{array}$ \\
\hline & & $\begin{array}{l}\text { Satisfaction of } \\
\text { coverage }\end{array}$ & $\begin{array}{l}\text { Water demand, water use, } \\
\text { coverage }\end{array}$ & $\begin{array}{l}\text { Milman \& Short, 2008; Allen et al., } \\
\text { 2006b; Schramm, 2011 }\end{array}$ \\
\hline & & $\begin{array}{l}\text { Regularity of the } \\
\text { service }\end{array}$ & $\begin{array}{l}\text { Frequency, time range of } \\
\text { service functioning }\end{array}$ & Cabrera, 2015; Moretto et al., 2018 \\
\hline & & Public health risk & $\begin{array}{l}\text { Water-borne and vector- } \\
\text { borne diseases, monitoring } \\
\text { activity }\end{array}$ & Yu et al., 2011, 2012 \\
\hline & \multirow{6}{*}{$\begin{array}{l}\text { Settlement / } \\
\text { Land }\end{array}$} & Land tenure & Formal, informal & $\begin{array}{l}\text { Winayanti \& Lang, 2004; Allen et } \\
\text { al., 2006b, } 2017\end{array}$ \\
\hline & & Land use & $\begin{array}{l}\text { Zoning, masterplans for the } \\
\text { area, pressures from } \\
\text { speculation }\end{array}$ & Bakker, 2003; Schramm, 2011 \\
\hline & & Environmental risk & $\begin{array}{l}\text { Flood prone areas, landslide } \\
\text { risk areas, contaminated } \\
\text { sites, steepness/altitude }\end{array}$ & $\begin{array}{l}\text { Winayanti \& Lang, 2004; Yu et al., } \\
2011\end{array}$ \\
\hline & & Urban morphology & $\begin{array}{l}\text { Open space, built space (high } \\
\text { density/low density) }\end{array}$ & $\begin{array}{l}\text { Schramm, 2011; Yatmo \& } \\
\text { Atmodiwirjo, 2012; Cabrera, } 2015\end{array}$ \\
\hline & & Location & $\begin{array}{l}\text { Central, urban, peri-urban, } \\
\text { rural }\end{array}$ & Schramm, 2011; Allen et al., 2017 \\
\hline & & History & $\begin{array}{l}\text { Settlement and infrastructure } \\
\text { consolidation }\end{array}$ & Cabrera, 2015 \\
\hline
\end{tabular}




\section{Table 2. Characteristics of WSS co-production in Addis Ababa, Hanoi and}

\section{Cochabamba: the actor dimension}

\begin{tabular}{|c|c|c|c|c|c|}
\hline D & $\mathbf{C}$ & $\mathbf{F}$ & $\frac{\text { Addis Ababa - Kebele }}{\underline{\text { areas }}}$ & $\frac{\text { Hanoi - Soviet Collective }}{\underline{\text { Blocks }}}$ & $\frac{\text { Cochabamba - Basic territorial }}{\text { organizations (OTBs) }}$ \\
\hline \multirow{10}{*}{$\frac{n}{2}$} & \multirow{6}{*}{ 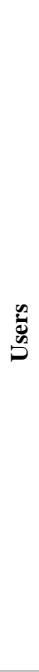 } & $\begin{array}{l}\text { Level of co- } \\
\text { production }\end{array}$ & $\begin{array}{l}\text { Co-funding and co-management } \\
\text { of shared water taps and shared } \\
\text { toilets (pit-latrine). }\end{array}$ & $\begin{array}{l}\text { Co-funding and co-management } \\
\text { of individual water infrastructure } \\
\text { - Co-management of shared } \\
\text { septic tanks and decentralized } \\
\text { sewerage system }\end{array}$ & $\begin{array}{l}\text { Co-planning, co-design and co- } \\
\text { management of collective water } \\
\text { network }\end{array}$ \\
\hline & & $\begin{array}{l}\text { Users' scale } \\
\text { of } \\
\text { involvement }\end{array}$ & $\begin{array}{l}\text { Water supply: Group co- } \\
\text { production / Sanitation: Group } \\
\text { co-production }\end{array}$ & $\begin{array}{l}\text { Water supply: Individual co- } \\
\text { production / Sanitation: Group } \\
\text { co-production }\end{array}$ & Collective co-production \\
\hline & & Role of users & $\begin{array}{l}\text { Water supply: Citizens/customers } \\
\text { / } \underline{\text { Sanitation: Citizens/clients }}\end{array}$ & $\begin{array}{l}\text { Water supply: Citizens/customers } \\
\text { / } \underline{\text { Sanitation: Citizens/clients }}\end{array}$ & Citizens/clients \\
\hline & & $\begin{array}{l}\text { Number of } \\
\text { users }\end{array}$ & Small groups (4-15 households) & $\begin{array}{l}\text { Large groups (around 100-200 } \\
\text { households) }\end{array}$ & Large groups (60-600 households) \\
\hline & & $\begin{array}{l}\text { End-users } \\
\text { motivation / } \\
\text { willingness }\end{array}$ & $\begin{array}{l}\text { Individual motivation to satisfy a } \\
\text { basic need collectively / Public } \\
\text { incentives through transfer of } \\
\text { materials }\end{array}$ & $\begin{array}{l}\text { Individual motivation from socio- } \\
\text { political duties / No public } \\
\text { incentives }\end{array}$ & $\begin{array}{l}\text { Pro-social motivation ('human right to } \\
\text { water') / Public incentives through } \\
\text { transfer of economic resources, } \\
\text { labour, materials }\end{array}$ \\
\hline & & $\begin{array}{l}\text { Norms and } \\
\text { social capital }\end{array}$ & $\begin{array}{l}\text { Low socio-economic capacity / } \\
\text { No data on forms of } \\
\text { collaboration and shared values }\end{array}$ & $\begin{array}{l}\text { Medium-low socio-economic } \\
\text { capacity / Revenue from } \\
\text { management for funding social } \\
\text { activities, events and solidarity }\end{array}$ & $\begin{array}{l}\text { Medium-low socio-economic capacity } \\
\text { / Revenue from management for } \\
\text { funding social activities, events and } \\
\text { solidarity / Strong community } \\
\text { relationships }\end{array}$ \\
\hline & \multirow{2}{*}{ 总 } & $\begin{array}{l}\text { Bodies in } \\
\text { charge and } \\
\text { type }\end{array}$ & $\begin{array}{l}\text { A member of users' group or a } \\
\text { user committee are responsible } \\
\text { for WSS infrastructure } \\
\text { management (security, } \\
\text { maintenance administration \& } \\
\text { revenue collection) / Private } \\
\text { companies can be contracted for } \\
\text { desludging }\end{array}$ & $\begin{array}{l}\text { A group of residents, members of } \\
\text { the local political body (TDP), is } \\
\text { responsible for sanitation } \\
\text { management (maintenance } \\
\text { administration \& fund collection } \\
\text { for desludging) / Private or public } \\
\text { companies can be contracted for } \\
\text { desludging and for repairing } \\
\text { breakages }\end{array}$ & $\begin{array}{l}\text { Local small-scale operators (OLPEs) } \\
\text { are responsible water infrastructure } \\
\text { management (security, maintenance } \\
\text { administration \& revenue collection) / } \\
\text { Private companies can be contracted } \\
\text { for well drilling, repairing breakages } \\
\text { or desludging. }\end{array}$ \\
\hline & & $\begin{array}{l}\text { Degree of } \\
\text { institutionaliz } \\
\text { ation }\end{array}$ & $\begin{array}{l}\text { Water supply: Committee is } \\
\text { formally elected by users and it is } \\
\text { directly connected with the local } \\
\text { government / Sanitation: } \\
\text { Committee is informally elected } \\
\text { by users / Costs of WSS } \\
\text { infrastructure operation and } \\
\text { maintenance sustained by users }\end{array}$ & $\begin{array}{l}\text { Sanitation: Resident's group is } \\
\text { formally elected by users and it is } \\
\text { directly connected with the local } \\
\text { government / Costs of sanitation } \\
\text { infrastructure operation and } \\
\text { maintenance sustained by users }\end{array}$ & $\begin{array}{l}\text { OLPE is formally elected by users. It } \\
\text { is formally recognised but } \\
\text { autonomous from the state. They can } \\
\text { be organized as cooperatives, } \\
\text { associations or basic territorial } \\
\text { organizations / Cost of operation and } \\
\text { maintenance sustained by OLPE from } \\
\text { water revenues (users' membership } \\
\text { fee and water tariffs) }\end{array}$ \\
\hline & \multirow{2}{*}{$\frac{0}{0}$} & $\begin{array}{l}\text { Form of } \\
\text { government }\end{array}$ & $\begin{array}{l}\text { Water supply: Centralized form } \\
\text { of government (water points } \\
\text { connected to the centralized } \\
\text { water network) / Sanitation: } \\
\text { Decentralized form of } \\
\text { government (on-site facilities) }\end{array}$ & $\begin{array}{l}\text { Water supply: Centralized form } \\
\text { of government (individual } \\
\text { connection to centralized water } \\
\text { network) / Sanitation: } \\
\text { Decentralized form of } \\
\text { government (on-site facilities and } \\
\text { sewage system) }\end{array}$ & $\begin{array}{l}\text { Decentralized form of government } \\
\text { (collective water network connected to } \\
\text { local boreholes, owned by users) }\end{array}$ \\
\hline & & $\begin{array}{l}\text { Responsible } \\
\text { agency and } \\
\text { type }\end{array}$ & $\begin{array}{l}\text { Public Water Authority operates } \\
\text { and maintains centralized } \\
\text { network up to the water meter, } \\
\text { and provides technical support } \\
\text { for building shared water points / } \\
\text { Lack of centralized sewerage } \\
\text { network in the area }\end{array}$ & $\begin{array}{l}\text { Water Companies under Public } \\
\text { Water Utility operates and } \\
\text { maintains the centralized network } \\
\text { up to the water meter / Lack of } \\
\text { centralized sewerage network in } \\
\text { the area }\end{array}$ & $\begin{array}{l}\text { State provides funding and technical } \\
\text { support to OLPEs / Public water } \\
\text { authority monitors water quality at } \\
\text { city scale / Lack of centralized water } \\
\text { network but presence of sewerage } \\
\text { networks in the area }\end{array}$ \\
\hline
\end{tabular}


Table 3. Characteristics of WSS co-production in Addis Ababa, Hanoi and Cochabamba: the flow dimension

\begin{tabular}{|c|c|c|c|c|c|}
\hline D & $\mathbf{C}$ & $\mathbf{F}$ & $\frac{\text { Addis Ababa - Kebele }}{\underline{\text { areas }}}$ & $\frac{\text { Hanoi - Soviet Collective }}{\underline{\text { Blocks }}}$ & $\frac{\text { Cochabamba - }}{\underline{\text { organizations (OTBs) }}}$ \\
\hline \multirow{9}{*}{$\frac{2}{x}$} & \multirow{5}{*}{ 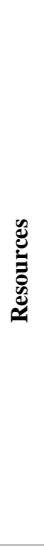 } & $\begin{array}{l}\text { Diversity of the } \\
\text { resource }\end{array}$ & $\begin{array}{l}\text { Surface water from centralized } \\
\text { intake works / Wastewater } \\
\text { discharged into the river }\end{array}$ & $\begin{array}{l}\text { Groundwater from well fields } \\
\text { (centralized network) / } \\
\text { Wastewater discharged into } \\
\text { channels and ponds }\end{array}$ & Groundwater from decentralized wells \\
\hline & & $\begin{array}{l}\text { "Qualities" of } \\
\text { resource }\end{array}$ & $\begin{array}{l}\text { No data on quality of water / } \\
\text { Increasing water scarcity at } \\
\text { regional level }\end{array}$ & $\begin{array}{l}\text { Low quality of water due to } \\
\text { heavy metals and biological } \\
\text { contamination / Adequate } \\
\text { quantity of water }\end{array}$ & $\begin{array}{l}\text { No data on quality of water / Limited } \\
\text { quantity of water (water table is } \\
\text { impacted by over pumping) }\end{array}$ \\
\hline & & $\begin{array}{l}\text { Scale of urban } \\
\text { water cycle }\end{array}$ & City level & City level & Local level \\
\hline & & $\begin{array}{l}\text { Environmental } \\
\text { programmes / } \\
\text { policies }\end{array}$ & No environmental programmes & $\begin{array}{l}\text { Community programs for } \\
\text { improving the quality of ponds } \\
\text { and lakes }\end{array}$ & No environmental programmes \\
\hline & & $\begin{array}{l}\text { Awareness of } \\
\text { resource } \\
\text { dynamics }\end{array}$ & No data & No data & $\begin{array}{l}\text { High level of community's awareness } \\
\text { of the quantity of the resources / } \\
\text { Mechanisms of control to contrast } \\
\text { freeriding of the resource }\end{array}$ \\
\hline & \multirow{4}{*}{ 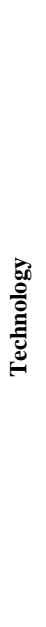 } & $\begin{array}{l}\text { Scale of } \\
\text { technology }\end{array}$ & $\begin{array}{l}\text { Water supply: Scale of } \\
\text { community } \\
\text { Sanitation: Scale of community }\end{array}$ & $\begin{array}{l}\text { Water supply: Scale of } \\
\text { households } \\
\text { Sanitation: Scale of the block }\end{array}$ & Scale of community/settlement \\
\hline & & $\begin{array}{l}\text { Technical } \\
\text { complexity }\end{array}$ & $\begin{array}{l}\text { Simple level (1-4 managers - } \\
\text { low technology) }\end{array}$ & $\begin{array}{l}\text { Simple level ( } 1 \text { representative - } \\
\text { low technology) }\end{array}$ & $\begin{array}{l}\text { Medium level ( } 1 \text { assembly - low } \\
\text { technology) / Availability of local } \\
\text { technicians / Users are responsible for } \\
\text { maintaining and cleaning periodically } \\
\text { the water tanks, and to participate to } \\
\text { assemblies }\end{array}$ \\
\hline & & Connectedness & $\begin{array}{l}\text { Water supply: combined system, } \\
\text { distributive } \\
\text { Sanitation: separated systems, } \\
\text { accumulative }\end{array}$ & $\begin{array}{l}\text { Water supply: combined system, } \\
\text { distributive } \\
\text { Sanitation: separated systems, } \\
\text { accumulative }\end{array}$ & $\frac{\text { Water supply: separated system, }}{\text { distributive }}$ \\
\hline & & $\begin{array}{l}\text { Infrastructure } \\
\text { portfolio }\end{array}$ & $\begin{array}{l}\text { Water supply: Secondary water } \\
\text { pipes, one water meter for shared } \\
\text { tap, jerry cans / Sanitation: pit } \\
\text { latrine, toilet lock }\end{array}$ & $\begin{array}{l}\text { Water supply: Tertiary water } \\
\text { pipes, booster pumps, elevated } \\
\text { water tanks and filtering, water } \\
\text { meter at households / Sanitation: } \\
\text { individual or shared toilets, septic } \\
\text { tank, secondary sewerage }\end{array}$ & $\begin{array}{l}\text { Water supply: well, pumping station, } \\
\text { piped network, booster pumps, } \\
\text { elevated water tanks, chlorination } \\
\text { systems, water meter at households }\end{array}$ \\
\hline
\end{tabular}


Table 4. Characteristics of WSS co-production in Addis Ababa, Hanoi and

\section{Cochabamba: the area dimension}

\begin{tabular}{|c|c|c|c|c|c|}
\hline D & $\mathbf{C}$ & $\mathbf{F}$ & $\frac{\text { Addis Ababa - Kebele }}{\underline{\text { areas }}}$ & $\frac{\text { Hanoi - Soviet Collective }}{\underline{\text { Blocks }}}$ & $\frac{\text { Cochabamba - }}{\text { organizations (OTBs) }}$ \\
\hline \multirow{10}{*}{$\stackrel{\mathscr{E}}{\sharp}$} & \multirow{4}{*}{ : } & Accessibility & $\begin{array}{l}\text { Low distance to WSS points / } \\
\text { Standard fixed price for water at } \\
\text { urban level }\end{array}$ & $\begin{array}{l}\text { Low distance to WSS points / } \\
\text { Standard fixed price for water at } \\
\text { urban level }\end{array}$ & $\begin{array}{l}\text { Low distance to WSS points / } \\
\text { Standard fixed price for water at urban } \\
\text { level }\end{array}$ \\
\hline & & $\begin{array}{l}\text { Satisfaction of } \\
\text { coverage }\end{array}$ & $\begin{array}{l}\text { Full coverage, not fully satisfied } \\
\text { demand - existence of } \\
\text { complementary water supply } \\
\text { modalities (water purchase) }\end{array}$ & $\begin{array}{l}\text { Full coverage, not fully satisfied } \\
\text { demand - existence of } \\
\text { complementary water supply } \\
\text { modalities (water purchase) }\end{array}$ & $\begin{array}{l}\text { Full coverage, not fully satisfied } \\
\text { demand - existence of complementary } \\
\text { water supply modalities (water } \\
\text { purchase) }\end{array}$ \\
\hline & & $\begin{array}{l}\text { Regularity of } \\
\text { the service }\end{array}$ & $\begin{array}{l}4-5 \text { days per week, in average / } \\
\text { hour rationing policies }\end{array}$ & $7 / 7$ days, $4 / 24$ hours per day & $\begin{array}{l}\text { Generally } 2-3 / \text { day a week, and few } \\
\text { hours a day }\end{array}$ \\
\hline & & $\begin{array}{l}\text { Public health } \\
\text { risk }\end{array}$ & No monitoring activity & No monitoring activity & No monitoring activity \\
\hline & \multirow{6}{*}{ 苞 } & Land tenure & $\begin{array}{l}\text { Formal land tenure system: multi- } \\
\text { familiar type of housing (kebele } \\
\text { house) at a low controlled rental } \\
\text { price }\end{array}$ & $\begin{array}{l}\text { Formal land tenure system, with } \\
\text { informal densification and } \\
\text { occupation of public space for } \\
\text { new dwellings }\end{array}$ & Mix of formal and informal areas \\
\hline & & Land use & $\begin{array}{l}\text { Existing resettlement strategy for } \\
\text { slum dwellers }\end{array}$ & $\begin{array}{l}\text { Existing resettlement strategy for } \\
\text { all dwellers living Soviet } \\
\text { Collective Blocks }\end{array}$ & No data \\
\hline & & $\begin{array}{l}\text { Environmental } \\
\text { risk }\end{array}$ & $\begin{array}{l}\text { Increasing water scarcity / Urban } \\
\text { rivers are high polluted / Frequent } \\
\text { flooding events in the rainy } \\
\text { season }\end{array}$ & $\begin{array}{l}\text { Urban rivers, channels and ponds } \\
\text { are high polluted / Frequent } \\
\text { flooding events in the rainy } \\
\text { season / Land subsidence }\end{array}$ & $\begin{array}{l}\text { Increasing water scarcity / Landslide } \\
\text { risk in mountainous areas }\end{array}$ \\
\hline & & $\begin{array}{l}\text { Urban } \\
\text { morphology }\end{array}$ & $\begin{array}{l}\text { High-density built areas, few } \\
\text { open spaces }\end{array}$ & $\begin{array}{l}\text { High-density built areas, } \\
\text { sufficient open spaces }\end{array}$ & $\begin{array}{l}\text { Low-density areas - morphology } \\
\text { influenced by pre-existing irrigation } \\
\text { canals }\end{array}$ \\
\hline & & Location & Urban & Urban & Peri-urban \\
\hline & & History & $\begin{array}{l}\text { Old settlement typology (slum) / } \\
\text { Use of shared water point is } \\
\text { currently reducing in favour of } \\
\text { private connection or secondary } \\
\text { buying/reselling activity / Urban } \\
\text { development implies a more } \\
\text { water-demanding infrastructure } \\
\text { (from poor-flush to normal-flush) }\end{array}$ & $\begin{array}{l}\text { State-driven development / } \\
\text { Originally, the infrastructure was } \\
\text { provided by the government and } \\
\text { users were sharing water from } \\
\text { collective water tanks and one } \\
\text { tap; later, the management of the } \\
\text { infrastructure has been } \\
\text { transferred to resident's groups } \\
\text { (sanitation) and households } \\
\text { (water) }\end{array}$ & $\begin{array}{l}\text { Occupancy-driven development / } \\
\text { Inhabitants need some years to raise } \\
\text { funds to build the water infrastructure } \\
\text { - Water networks do not follow a clear } \\
\text { urban pattern }\end{array}$ \\
\hline
\end{tabular}


Figure 1. The co-production system

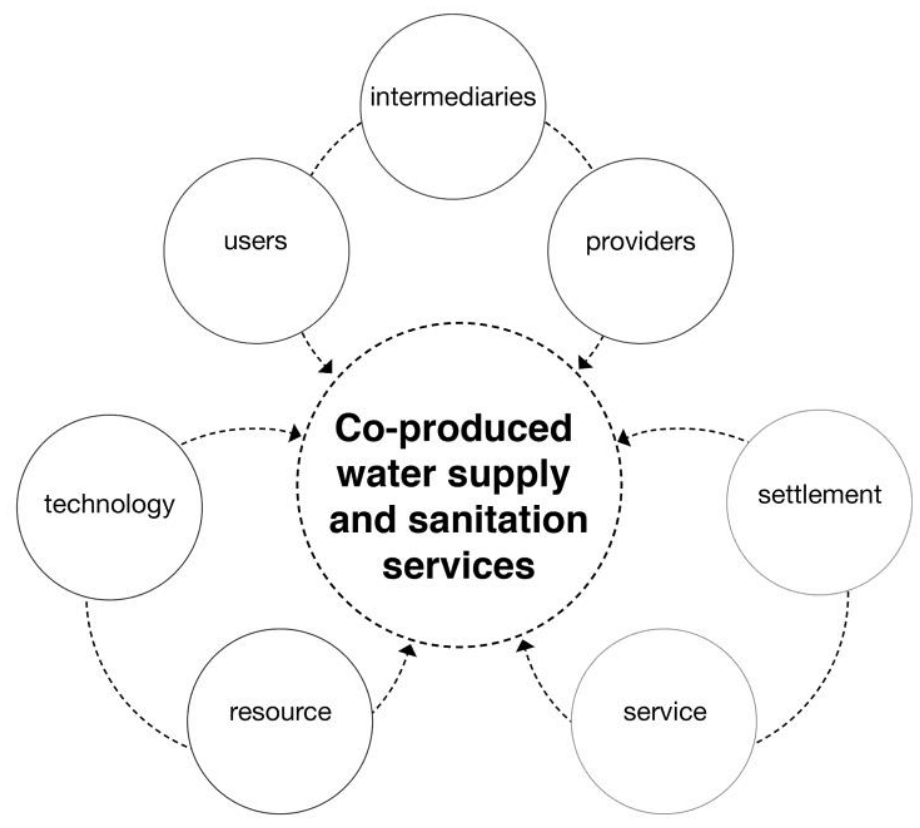

Figure 2. The socio-technical framework: E-End-users; P-Providers: R-Resources; TTechnology (Yu et al., 2012, p. 2734, adapted from van Vliet et al., 2005)

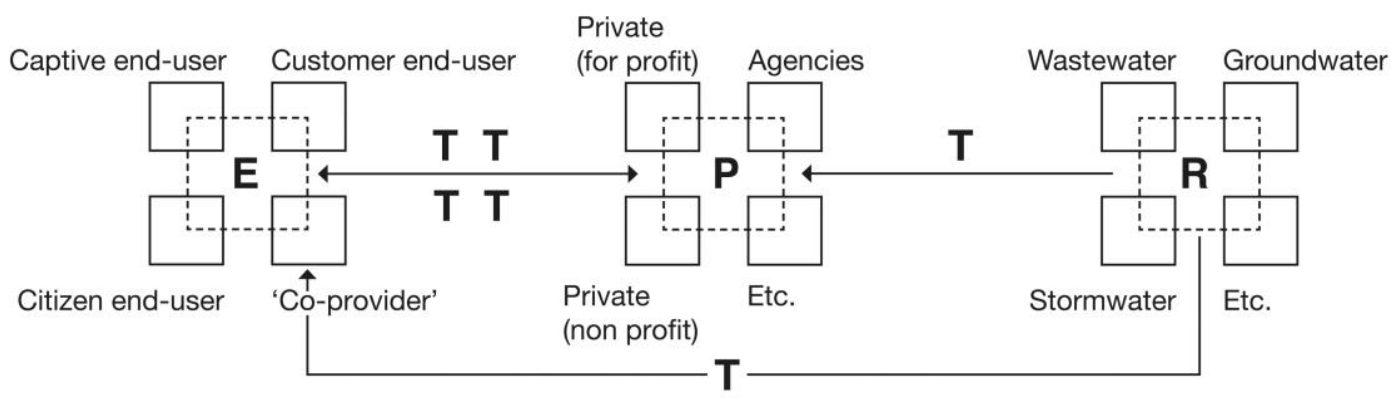

${ }^{i}$ By referring to Mitlin and Satterthwaite (2013, p. 13), we use the term "Global South" to "include all nations classified by the World Bank as low- and middle-income that are in Africa, Asia and Latin America and the Caribbean”. 
${ }^{\text {ii }}$ Africa, Asia and Latin America showed the highest average annual rate of urban population growth, respectively 3.44\%, 2.78\% and 1.45\% in the period between 1995 and 2015 (United Nations Human Settlements Programme [UN-Habitat], 2016).

iii The normative perspective looks at the values that could be embedded in the process of coproducing - such as social justice, democracy and citizens' empowerment - whatever the final results of the practice are. The instrumental/pragmatic perspective looks at the values that could be embedded in the outcome of a co-produced practice, such as improved efficiency and quality of the service. 